\title{
Microbial and Biochemical Ghanges during the Moulding of Hay
}

\author{
By P. H. GREGORY, MAUREEN E. LACEY, G. N. FESTENSTEIN \\ AND F. A. SKINNER \\ Rothamsted Experimental Station, Harpenden, Hertfordshire
}

(Received 29 April 1963)

\begin{abstract}
SUMMARY
Experimental batches of hay were baled at different moisture contents, and the microbial and biochemical changes studied by sequential sampling. The type of hay obtained could, in general, be related to the initial moisture content, and to the temperature subsequently attained. Good hays (about $16 \%$ moisture) heated little and contained a small but diverse microflora. Hays baled at about $25 \%$ moisture heated to about $45^{\circ}$ and moulded, mainly with Aspergillus glaucus. Wet bales, with initial moisture contents of about $40 \%$, became very hot $\left(60^{\circ}-65^{\circ}\right)$ and contained a large flora of thermophilic fungi, particularly Aspergillus fumigatus, Absidia spp., Mucor pusillus, Humicola lanuginosa, and actinomycetes. During the initial heating period, which was correlated with a general rise in numbers of micro-organisms, particularly actinomycetes and bacteria, the acidity and volatile nitrogen increased. Later, when fungi and actinomycetes grew profusely, soluble sugars decreased rapidly and the $\mathrm{pH}$ value rose to $7 \cdot 0$ or above. Stacks of wet and dry hays were compared with bales made from the same hays. The wet stack developed a core of brown acid hay, containing many sporeforming bacteria but few fungi, surrounded by a layer of mouldy hay.
\end{abstract}

\section{INTRODUCTION}

This work was begun to obtain information in connexion with human and animal diseases ascribed to the inhalation of dust from mouldy hay. Hays thought to have caused Farmer's Lung disease contained many thermophilic moulds and actinomycetes (Gregory \& Lacey, 1963a), but these hay samples were the quiescent endproducts of a process, and we needed to know what factors during hay-making produced the various recognizable types of hay. The major factor seemed likely to be the moisture content of the herbage at the time of baling.

In 1959 experiments were started at Rothamsted to follow changes in batches of mainly grass hay baled at different moisture contents; sequential measurements were made of temperature, moisture content, numbers of fungi, actinomycetes and bacteria in seven batches (P.H.G. and M.E.L.). Changes in chemical constituents of stored wet hay have been recorded (Hoffman, 1935; Hoffman \& Bradshaw, 1937; Roethe, 1937) but they were not correlated with detailed microbial studies. Accordingly in 1960 sequential samples used for microbial analysis were also studied biochemically (G.N.F.). In 1961 changes in the bacterial population were also studied (F.A.S.). Earlier work on the microbiology of hay has been related to the 
problem of self-heating in damp haystacks and the occasional hazard of spontaneous combustion (Miehe, 1930). Bales and stacks of wet and dry hay were compared in 1961. Each batch of hay was studied for 1 season only.

\section{METHODS}

Haymaking. The grass used came from non-experimental fields on the Rothamsted farm; in 1959 and 1960 the grass was usually tedded only, but in 1961 it was also crushed twice with a forage harvester. Samples taken frequently during wilting were oven-dried to determine water content so that baling could be timed to give batches at the different required moisture contents. Bales measuring about 42 by 18 by 14 in. were made with a ' $\mathrm{B} 55$ ' baler (International Harvester Co.), and stored under cover.

Studies on bales. Temperature changes in the bales were measured either with mercury-in-steel thermographs or with distance-reading bimetallic thermometers inserted into the bales. Sampling methods differed from year to year; details are given under the separate sections. Moisture content was determined from a subsample either by oven-drying, or (in 1961 only) by freeze-drying.

\section{Examination of dust}

Microbial investigations

For general microbial examination of dust, 20-30 g. hay were shaken in a perforated zinc drum in a wind tunnel (Gregory \& Lacey, 1963 $b$ ). The dust removed in a wind of $4.2 \mathrm{~m}$./ $/ \mathrm{sec}$. was sampled with: (1) the Cascade impactor (May, 1945) for visual examination of the wind-blown microflora (2) the Liquid Impinger (Rosebury, 1947) in 1959, and the Andersen Sampler (Andersen, 1958) in 1960 and 1961, to isolate micro-organisms in culture. Fungi were isolated on $2 \%$ malt extract agar containing 20 units penicillin $/ \mathrm{ml}$. and 40 units streptomycin $/ \mathrm{ml}$. Actinomycetes and bacteria were isolated on half-strength Oxoid nutrient agar containing $0.5 \mathrm{mg}$. actidione $/ \mathrm{ml}$. Fungi were incubated at $25^{\circ}$ and $40^{\circ}$, and actinomycetes and bacteria at $25^{\circ}, 40^{\circ}$ and $60^{\circ}$ (see Gregory \& Lacey, 1962).

\section{Examination of washings}

In 1961 the bacteria and other organisms present were also studied by plating-out washings. On each sampling occasion one subsample was used for analysis of the wind-blown microflora as described above. Hay from a second subsample was cut into $2-3 \mathrm{~cm}$. lengths, thoroughly mixed, and $10 \mathrm{~g}$. shaken mechanically with sterile water for $10 \mathrm{~min}$. to prepare a suspension for bacteriological analysis. Serial dilutions were plated with nutrient agar, and replicate plates incubated at $25^{\circ}, 40^{\circ}$ and $60^{\circ}$. Some dilutions were also plated on the acetate agar of Keddie (1951) to detect and enumerate lactobacilli. Double-layer plates were used and the cultures incubated at $35^{\circ}$. Anaerobes were determined by the method of Ingram \& Barnes (1956) with Oxoid R.C.M. agar at $35^{\circ}$. Some of the cut hay was used for chemical analysis and moisture determinations as described below. 


\section{Biochemical investigations}

In 1960, $30 \mathrm{~g}$. of each hay sample was shredded, freeze-dried, milled and stored at $4^{\circ}$ until analysed; in $196150 \mathrm{~g}$. of each sample was freeze-dried and stored at $-20^{\circ}$.

Lipids were extracted with boiling chloroform + methanol $(2+1$, by vol.) ( $1 \mathrm{~g}$. dry hay/100 ml.) for $7 \mathrm{hr}$., the extracts purified by constituting in chloroform + methanol + water $(80+20+\mathbf{2} \cdot 5$, by vol. $)$ and passage through a column of Whatman cellulose powder, with $\mathbf{2 0}$ g. powder/g. lipid (Dr G. A. Garton, personal communication). Iodine values were determined by the method of Trappe (1938) on $1 \mathrm{ml}$. quantities of lipid extract after evaporation in vacuo. Lipids were analysed only in 1960 .

Water-soluble extracts were made by heating $0 \cdot 3 \mathrm{~g}$. dry hay with $22.5 \mathrm{ml}$. water for $30 \mathrm{~min}$. (Waite \& Gorrod, 1959) at $90^{\circ}$ and used to estimate glucose, soluble-N and volatile-N. Soluble-N and volatile- $\mathbf{N}$ were also estimated after extraction of hay with $0 \cdot 1 \mathrm{~N}-\mathrm{HCl}$ at room temperature for $24 \mathrm{hr}$. (Brady, 1960). Dry matter of aqueous extracts was determined by drying at $90^{\circ}$ for $48 \mathrm{hr}$. (1960 only). In 1961, reducing and non-reducing sugars, amide- $\mathbf{N}$ and titratable acidity were also estimated in the aqueous extracts.

Glucose was specifically estimated by glucose oxidase (Huggett \& Nixon, 1957) after removing the interfering colour with $5 \%(\mathrm{w} / \mathrm{v}) \mathrm{ZnSO}_{4}+0 \cdot 3 \mathrm{~N}-\mathrm{NaOH}$. The preparation of crude glucose oxidase used (Sigma Chemical Co.) was free from invertase, a contaminant of some other preparations (Howard, 1959). Reducing sugars were estimated by the colorimetric method of Nelson (1944) as modified by Somogyi (1952); non-reducing sugars were hydrolysed with $1 \%(\mathrm{w} / \mathrm{v})$ oxalic acid for $1 \mathrm{hr}$. at $100^{\circ}$ and estimated by the increment in reducing sugar (Macpherson, Wylam \& Ramstad, 1957).

Nitrogen was determined by a micro-Kjeldahl method; volatile-N was measured after steam distillation of 5-10 $\mathrm{ml}$. extract in a Markham still in the presence of borate buffer ( $\mathrm{pH} 9 \cdot 5$; Macpherson, 1952) amide- $\mathrm{N}$ was estimated by the increase in volatile- $\mathrm{N}$ after heating for $3 \mathrm{hr}$. at $100^{\circ}$ in $\mathrm{N}-\mathrm{H}_{2} \mathrm{SO}_{4}$ (Macpherson, 1952).

$\mathrm{pH}$ values were measured electrometrically on filtered extracts made by macerating $0.5 \mathrm{~g}$. dried sample $/ 50 \mathrm{ml}$. water in a top-drive high-speed macerator for $2 \mathrm{~min}$. (in 1960). In $1961 \mathrm{pH}$ measurements were made on aqueous suspensions of fresh hay. Titratable acidity was measured by titration with $0.01 \mathrm{~N}-\mathrm{NaOH}$, with phenolphthalein as indicator.

\section{RESULTS}

Experimental hay from New Zealand Field, June 1959

Batch $\mathrm{E}$ was baled at $42 \%$ water content on 8 June; Batch $\mathrm{N}$ at $28 \%$ water content on 10 June; Batch L at $16 \%$ water content on 15 June.

A mixed grass and herb ley was cut for hay on 4 June 1959 and batches baled at intervals as indicated above. Each batch of 10 bales was reasonably uniform in water content. One bale of each batch was stored under cover and sampled periodically; the remaining 9 bales were stacked in a barn and used to record temperature changes. On 10 July some of the Batch $\mathbf{N}$ bales in the barn were wetted by rain and 4 days later had heated to $70^{\circ}$. One of these bales $(R)$ was stored under cover and sampled. A little loose hay from Batch $\mathbf{N}$ was piled on the 
ground in the open for 4 months $(\mathbf{G n})$. Also, samples of Batches $\mathbf{E}$ and $\mathbf{N}$ were incubated in small sealed tins at $25^{\circ}$ or $40^{\circ}$ for 1 week.

Batch $\mathrm{E}$ heated to $65^{\circ}$ in 3 days, remained steady for several days and cooled to $24^{\circ}$ by the 14th day. The single bale used for sampling behaved similarly. Batch $\mathrm{N}$ heated to $40^{\circ}$ and remained at this temperature for 2 weeks. Batch $\mathrm{L}$ reached $30^{\circ}$ and remained steady during this same 2-week period; afterwards Batches $\mathbf{N}$ and $\mathrm{L}$ both cooled slowly.

Microbial changes. In Batch $\mathrm{E}$ the number of fungus spores increased rapidly and reached a maximum of nearly 10 million/g. dry wt. hay 7 days after baling. This number remained fairly constant over 2 months, but the species composition changed. At first, mainly thermophilic moulds, such as Absidia spp., Mucor pusillus, Aspergillus fumigatus and A. nidulans, developed. These were followed by Humicola lanuginosa and $\boldsymbol{H}$. stellata (Bunce, 1961) and later still by Scopulariopsis brevicaulis. In Batch $\mathbf{N}$, the number of fungus spores reached a higher maximum than in Batch E (nearly 100 million/g. 37 days after baling), but increased less rapidly and were mainly Aspergillus glaucus, a mesophilic mould. Batch L was dry and had few fungus spores throughout $(<1$ million spores/g.). Fungus species found in the 1959 hays are listed in Tables 1 and 2.

The small samples incubated in tins developed similarly to bales of the same water content and temperature. Batch $\mathbf{N}$ incubated at $25^{\circ}$ produced many spores of Aspergillus glaucus; Batch $\mathrm{E}$ at $40^{\circ}$ produced many thermophilic fungi. Specimen Gn developed many spores of Cladosporium, Tricothecium roseum, Penicillium and other mesophilic moulds.

Both Batch $\mathbf{E}$ and bale $\mathbf{R}$ showed a rapid and striking increase in actinomycetes and bacteria associated with self-heating of the hay to about $60^{\circ}$ (nearly 100 million organisms/g. after 7 days). By contrast Batches $\mathrm{N}$ and $\mathrm{L}$ developed few actinomycetes (rarely exceeding 1 million/g.). Many mesophilic actinomycetes and bacteria developed in $\mathbf{G n}$.

\section{Experimental hay from West Barnfield, July 1959}

An Italian rye-grass and red clover ley was cut on 7 July 1959 and 6 bales were made on 10 July with $25 \%$ water content (D); the remaining grass was wetted by rain in the field. On the morning of 13 July some of the wettest was placed in a Polythene bag at $64 \%$ water content (T1) and stored in the laboratory. The rest was baled later on the same day at $26 \%$ water content (T2). D reached a maximum of $40^{\circ} 7$ days after baling and maintained this for 4 days. T1 reached $30^{\circ}$ for several days and $\mathrm{T} 2$ reached $45^{\circ}$ in 7 days and then gradually cooled.

Microbial changes. D developed a similar fungus flora to $\mathrm{N}$ of the ' $\mathrm{New}$ Zealand' field series; with a maximum of $\mathbf{4 0}$ million spores/g., mostly Aspergillus glaucus. T1 had a maximum of 12 million spores/g., mostly Cladosporium and Tricothecium roseum. T2 produced a maximum of 48 million spores/g., mainly $A$. glaucus with many Cladosporium.

An interesting result from this series, and also from Gn of the previous series is the development of Tricothecium roseum, Cladosporium, Epicoccum, Alternaria and Acremoniella atra in hay that got wet and then took a long time to dry in the field. Few actinomycetes and bacteria developed in $\mathrm{D}$ and $\mathrm{T} 2$ but $\mathrm{T} 1$ had many mesophilic, with a few thermophilic actinomycetes. 


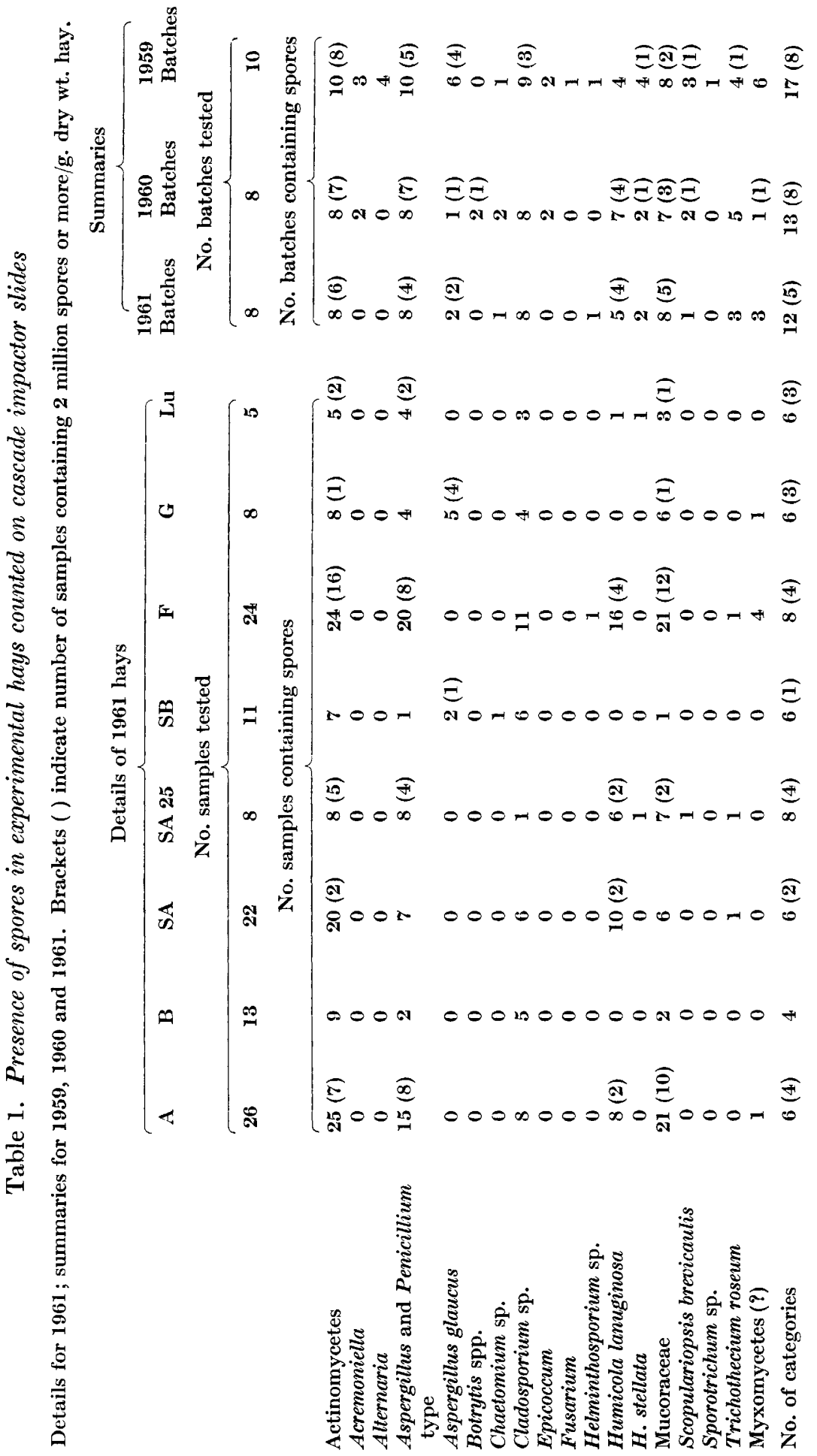




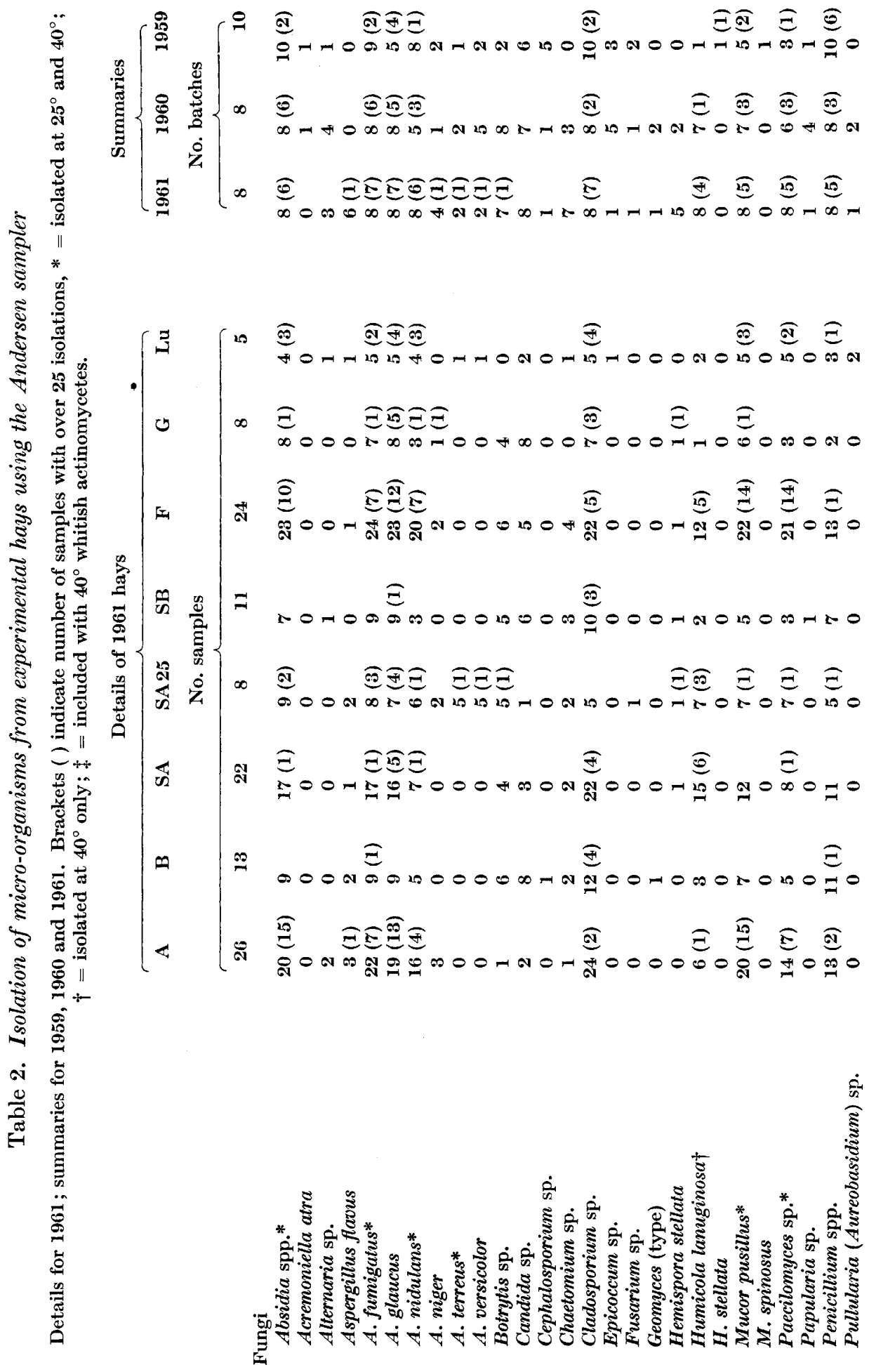




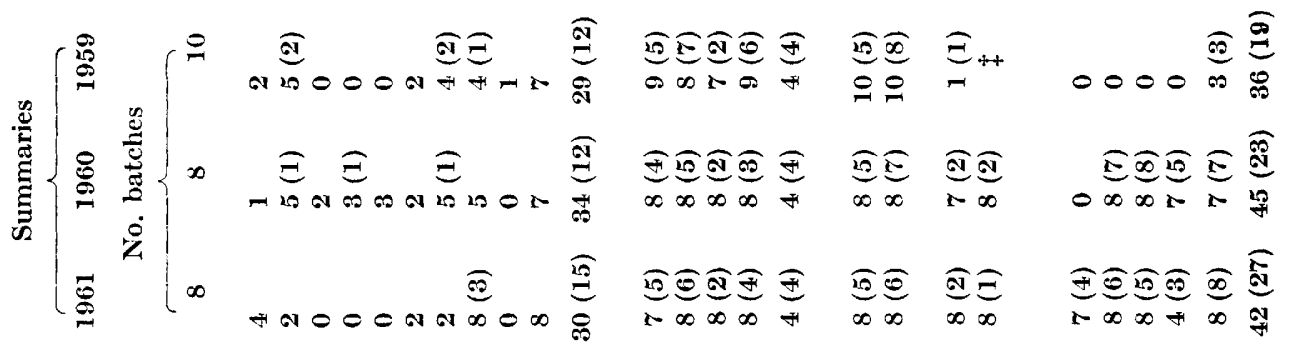

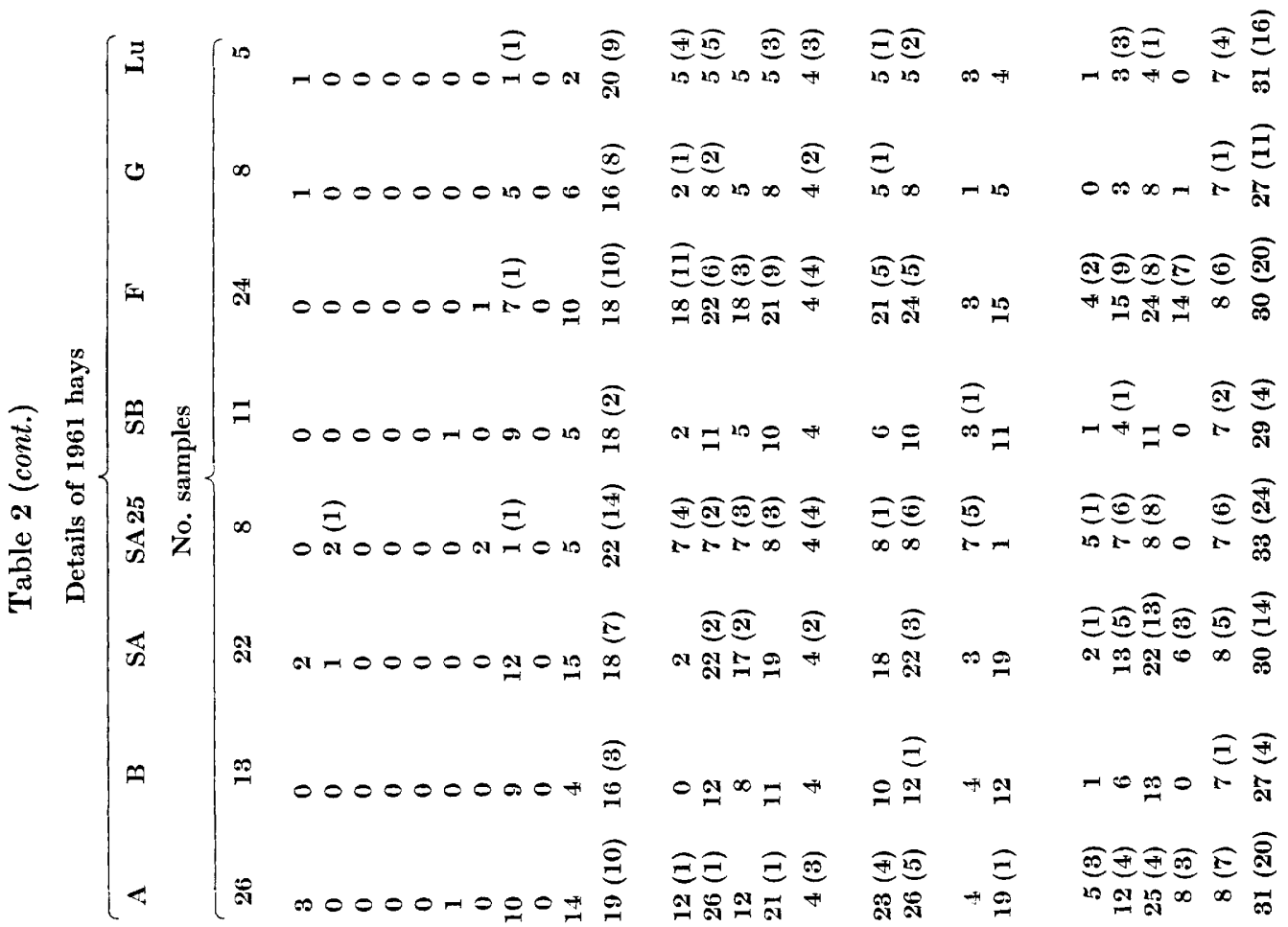

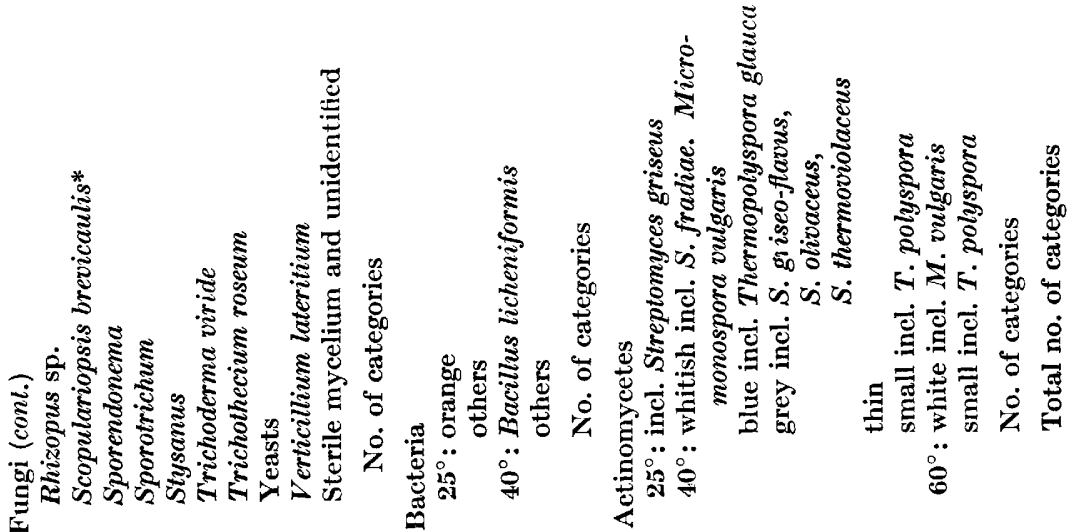




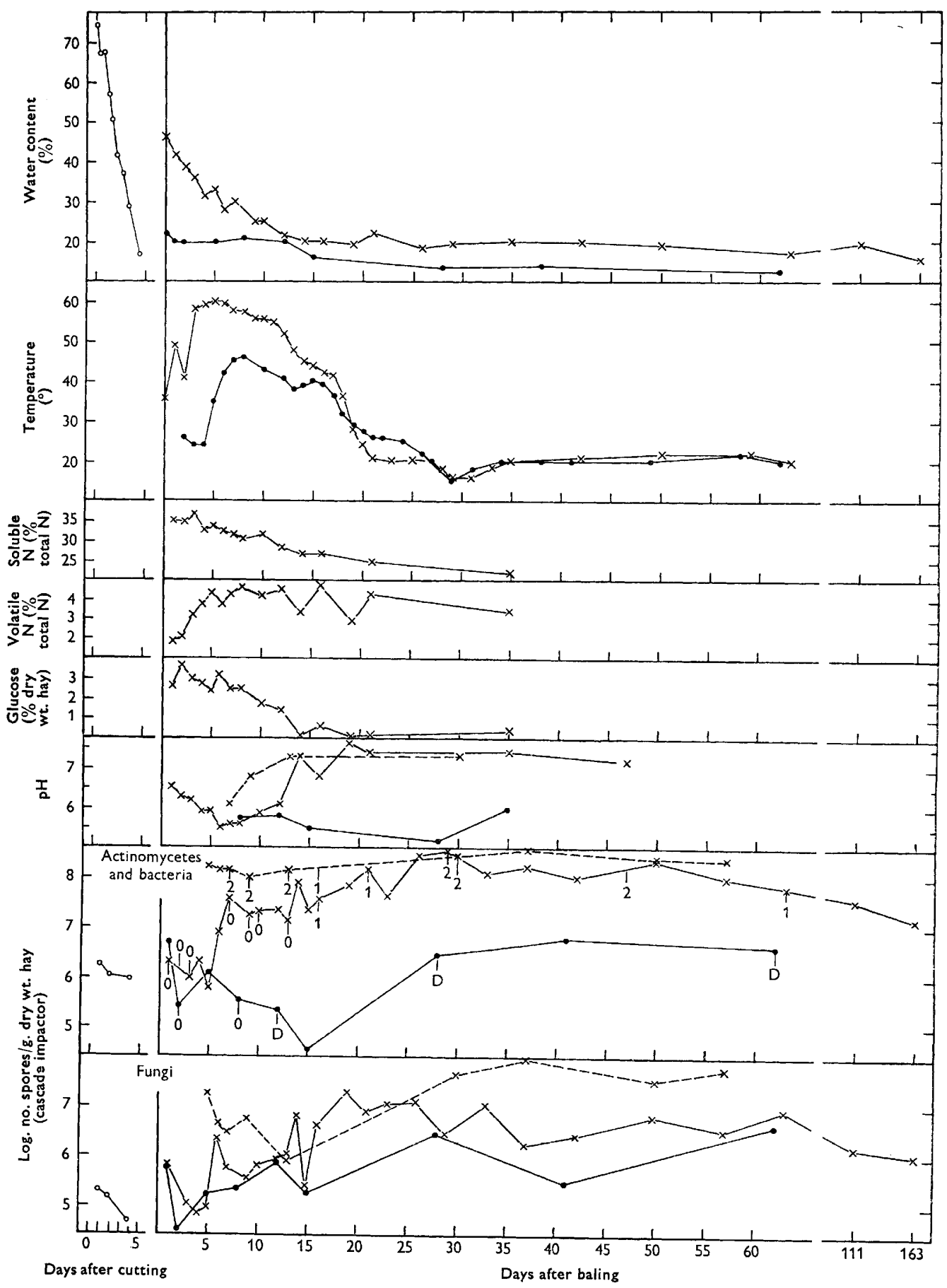

Fig. $1 a$. Changes in wet and dry baledh ays of Great Field made in June 1960. $\times-\times$, Batch W; $\times---\times$, Batch W2; - , Batch Y; $\bigcirc-0$, grass drying in the field. Serological reactions are shown on the graph for actinomycetes and bacteria: the figure indicates the number of precipitin bands in gel-diffusion tests; the letter $D$ indicates a diffuse precipitin band. 


\section{Experimental hay from Great Field, June 1960}

Batch W baled at $46 \%$ water content on 1 June; Batch W2 (fast moulding part of top bale of $\mathbf{W})$; Batch $\mathrm{X}$ baled at $39 \%$ water content on 1 June; Batch $\mathrm{Y}$ baled at $25 \%$ water content on 2 June; Batch $\mathrm{V}$ baled at $26-38 \%$ water content on 3 June.

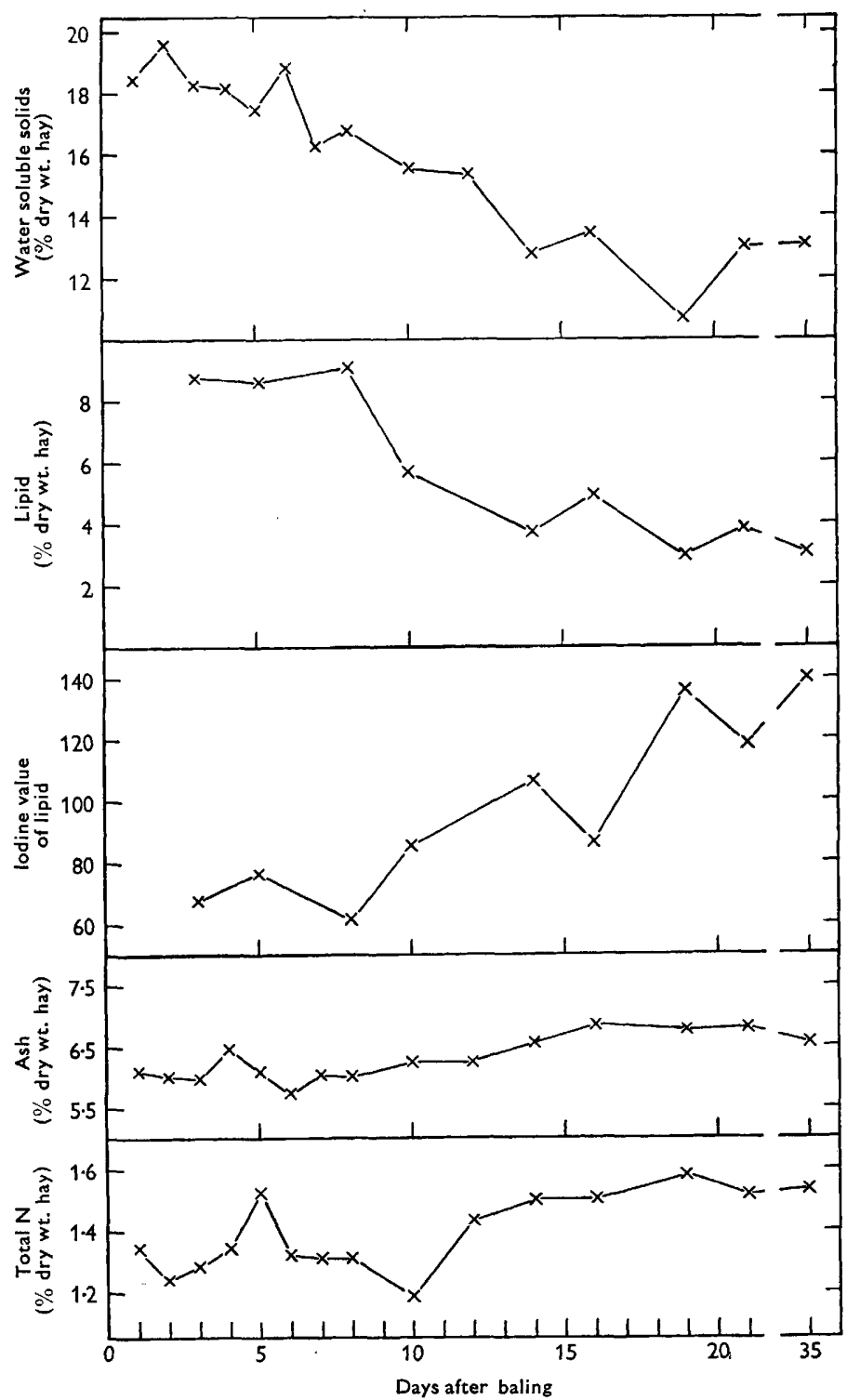

Fig. 1b. Chemical changes in W hay of Great Field, made in June 1960.

The timothy and fescue grass ley in Great Field was cut for hay on 30 May and baled at intervals as shown above. The drying and damping of this grass by dew was studied by Long (1961). Each batch of experimental hay, which consisted of 7 bales, was fairly uniform except for $\mathrm{V}$ (26-38\% water content), and to a lesser 
extent X (39\% water content). Batches of bales were stored in a barn in separate stacks with the bales arranged in layers of 3, 3 and 1. Temperature records and samples were taken from the centre bale, the single bale on top being rolled aside for sampling, and each day's sample of about $30 \mathrm{~g}$. was taken next to the previous sampling position. During the early sampling of $\mathbf{W}$, the side of the top bale was seen to be moulding quickly, so extra samples were taken from this area (W2).

Temperature changes. The temperature of the damp hays rose rapidly to maxima of: $\mathrm{V}=56^{\circ}, \mathrm{W}=60^{\circ}, \mathrm{X}=59^{\circ}$ and $\mathrm{Y}=46^{\circ}$.

Microbial changes. Fig. 1 a shows changes in number of spores after baling $\mathrm{W}$, $\mathbf{W} 2$ and $\mathbf{Y}$. Batch $\mathbf{X}$ and the damp bales of $\mathbf{V}$ behaved like $\mathbf{W}$, and the drier bales of $\mathrm{V}$ like $\mathrm{Y}$.

Fungi. Fungus spores increased rapidly in W and W2, consisting mainly of thermophilic moulds ('Tables 1, 2) and including Aspergillus spp., Absidia spp., Mucor pusillus, Humicola lanuginosa, H. stellata, and then Paecilomyces variotii. Batch $\mathbf{X}$ and the damp bales of $\mathbf{V}$ moulded slightly slower and produced fewer spores (maximum of 27 million/g. in $\mathrm{X} ; 10$ million in V). Batch $\mathrm{Y}$ was a less good control for the series than $\mathrm{L}$ had been in 1959, because it moulded with Aspergillus glaucus and a few thermophilic moulds.

Actinomycetes and bacteria. The increase in actinomycetes and bacteria in $\mathrm{W}$ and W2 is associated with the high temperature reached during self-heating (Fig. 1a). $\mathrm{Y}$ heated less and had few spores. In $\mathrm{X}$ the most counted was 134 million/g. dry wt., and in the damp bales of V 208 million. Table 2 gives more details of the actinomycetes isolated (and see Discussion).

Biochemical changes (Batch $W$ ). During the first 6 days after baling, while the temperature rose to and was maintained near $60^{\circ}$, the $\mathrm{pH}$ value decreased from 6.5 to $\mathbf{5 \cdot 5}$, and volatile- $\mathrm{N}$ increased rapidly, corresponding to the increase in actinomycetes and bacteria (Fig. 1a). Browne (1929) suggested that micro-organisms produce unsaturated compounds during self-heating of hay, but in $\mathrm{W}$ the iodine number of the lipids changed only slightly while the temperature was at its highest; an appreciable rise occurred only after 14 days when the temperature had dropped below $50^{\circ}$ and numbers of fungi had increased considerably (Fig. $1 b$ ). Increase in fungi was also associated with losses in glucose, lipid, soluble dry matter and soluble- $\mathrm{N}$, and with a rise in $\mathrm{pH}$ value, which rose to $\mathbf{7 \cdot 6}$; but there was no corresponding increase in volatile- $\mathbf{N}$, which suggests metabolism of fatty acids by fungi rather than increased ammonia production. A slight increase in ash content occurred during moulding, associated with the loss in glucose; the slight increase in total-N accompanying the increase in ash content was probably not a true increase either, but also reflected the loss of dry matter as glucose.

\section{Experimental hay from Great Field, September 1960}

Batch S heaped under cover at $65 \%$ water content, on 10 September; Batch $\mathbf{P}$ baled at $17 \%$ water content on 14 September and stored in barn; Batch Q baled at $17 \%$ water content on 14 September, left out in rain until 13 October.

The timothy and fescue ley in Great Field was cut for a second hay crop on 8 September 1960, crushed by forage harvester to aid drying, and tedded. A pile of grass (about $65 \%$ water content; S) about $1 \mathrm{~m}$. diameter and $1 \mathrm{~m}$. high was made on 10 September. This was covered with a metal sheet, and a thermograph inserted. 
The temperature rose to $52^{\circ}$ in 4 days, and cooled to $18^{\circ}$ by the 10 th day after piling. Traces of rain fell on 11 and 12 September, and the rest of the crop in the field had already moulded a little when baled on 14 September. To test the effect of rain wetting bales left out in the field, 4 bales $(Q)$ were left in the open, and by the time they were moved to the barn they had received $5 \mathrm{in}$. (127 mm.) of rain. The bale temperature usually fell during rain but rose again soon after the rain ceased, reaching maximum of $40^{\circ}$ on 23 September in the open, and on 15 October in the barn, on both occasions a short time after a thorough soaking. Four bales taken to the barn directly after baling $(\mathrm{P})$ reached a maximum of $\mathbf{2 2}^{\circ}$.

\section{Microbial changes}

Fungi. Specimens $\mathrm{S}$ and $\mathrm{Q}$ developed the usual thermophilic fungi. On the 10th day after piling $S$ had 20 million spores/g., 11 million of which were Humicola lanuginosa. Q contained 21 million spores/g., including those of a pink Sporotrichum-like form growing at $40^{\circ}$ but not at $25^{\circ}$. Trichothecium roseum was isolated from 4 of the 6 samples from $\mathbf{Q}$. Few fungi developed in $\mathbf{P}$.

Actinomycetes and bacteria. The striking rise in temperature of the pile $\mathrm{S}$ was associated with a rapid increase in actinomycetes to 89 million/g. by the 10 th day after piling. Of the 25 million spores/g. in $\mathrm{Q}$, many were not thermophilic. $\mathrm{P}$ developed few actinomycetes.

\section{Experimental hay from Great Field, June 1961}

Batch A baled at $30 \%$ water content on 5 June, stored in barn; Batch SA stacked at $30 \%$ water content on 5 June, stored under sheet in field; Batch B baled at $15 \%$ water content on 6 June, stored in barn; Batch SB stacked at $15 \%$ water content on 6 June, stored in barn.

The timothy and fescue grass ley in Great Field (used in 1960) was again cut for hay on 31 May 1961. The grass was very thick in the stand and although it was crushed twice and tedded several times it dried slowly and unevenly. These changes in farm practice made the batches of hay in 1961 more heterogeneous than in the previous years, and there was greater irregularity in samples taken for analysis. Each sample from the bales was taken by removing about five slices. From one of these, a sample was taken for blowing in the wind tunnel and the rest was mixed before sampling for bacteriological and biochemical examinations (Methods). The remaining four slices were sent to Dr J. Pepys, Institute of Diseases of the Chest, Brompton Hospital, London, for immunological work.

The wet (SA) and dry (SB) stacks were made $15 \mathrm{ft}$. diameter and $12 \mathrm{ft}$. high, and each was equipped with a horizontal $6 \mathrm{in}$. diam. asbestos pipe about $2 \mathrm{ft}$. from the ground and extending from the periphery to the centre. Samples were periodically withdrawn from the centre of a stack through the pipe by using a large hook bent for the purpose from $\frac{1}{2}$ in. square steel bar. After sampling, the outer end of the pipe was closed with a wad of hay to restrict aeration and minimize heat loss. Samples were taken from bales and stacks frequently over a period of 80 days (Figs. $2 a$ to $3 b$ ). Finally, in early December when 186 days had elapsed, the wet stack (SA) was cut open and single samples taken from eight different parts (Fig. 4). Table 3 shows the results of the analyses on these samples.

Temperature and moisture changes. The temperature of $\mathrm{A}$ rose to $55^{\circ}$ in 1 bale 
but, as the hay was unevenly dried, some areas in this batch did not heat above $48^{\circ}$ (compare V, 1960). Moisture content fell, but, as Fig. $2 a$ shows, different parts of any one bale differed in moisture content (the samples from days 1-4 after baling were from the same bale). $\mathrm{B}$ hardly heated at all and the moisture content decreased only slightly. Temperatures in the stack SA were recorded with two dial thermometers

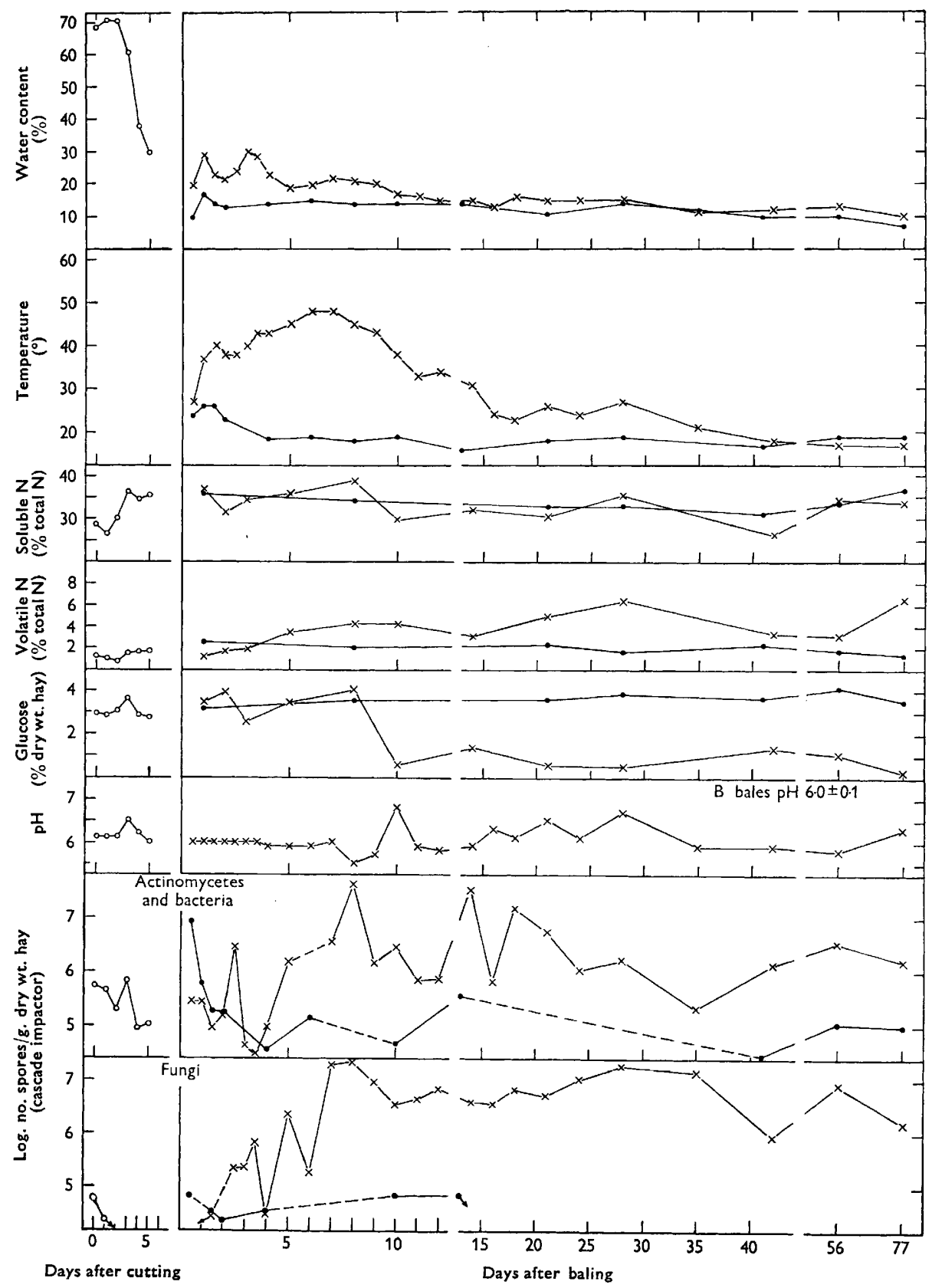

Fig. 2a. Changes in wet (A) and dry (B) baled hays of Great Field, made in June 1961. $\times$, Wet bales (A); 9 , dry bales $(B)$; $O$, grass drying in the field. 


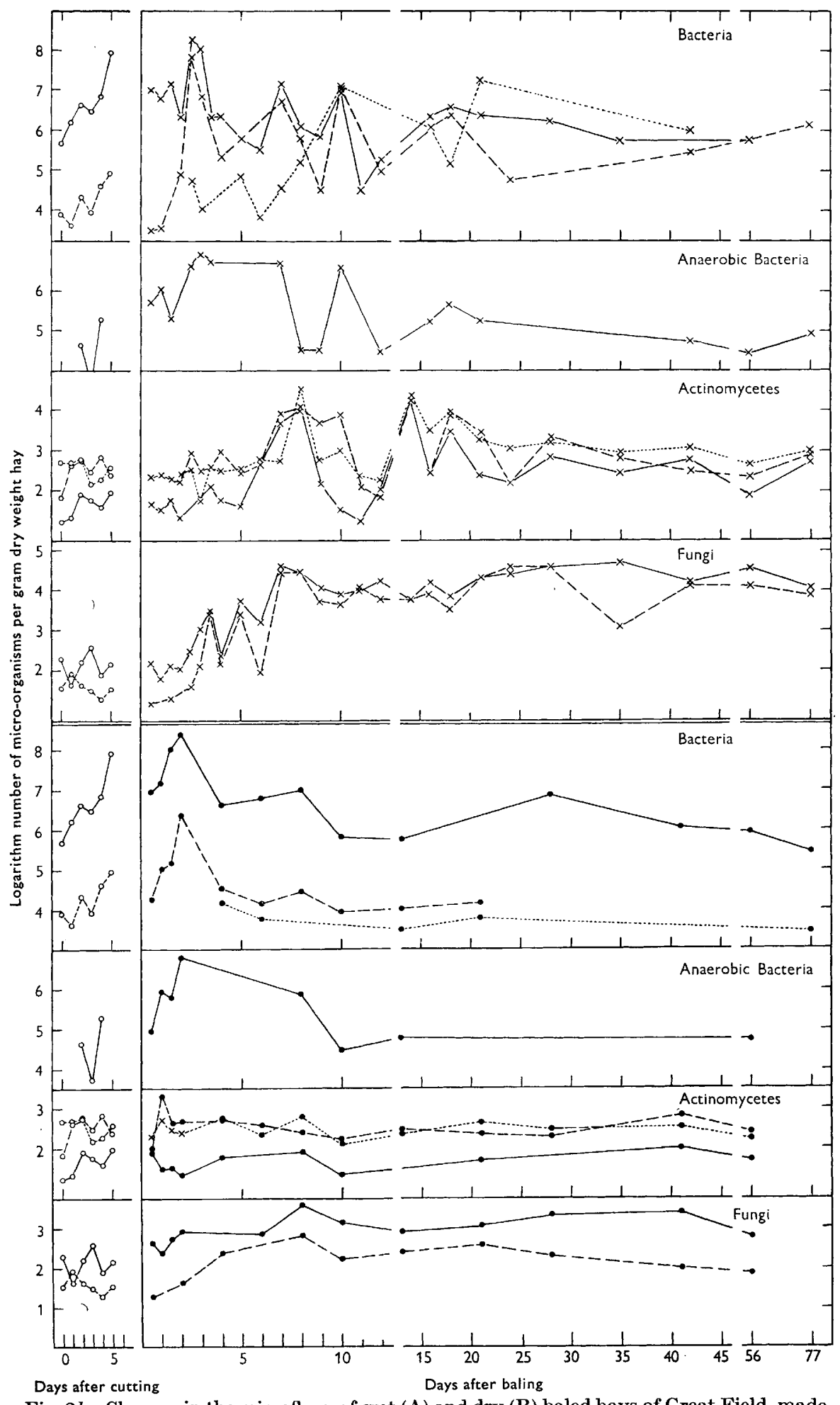

Fig. 2b. Changes in the microflora of wet $(A)$ and dry $(B)$ baled hays of Great Field, made in June, 1961. $\times$, Wet bales (A); $O$, dry bales (B); $O$, grass drying in the field. $\longrightarrow, 25^{\circ} ;---, 40^{\circ} ; \ldots, 60^{\circ}$. 
one $5 \mathrm{ft}$. long, the other $3 \mathrm{ft}$., read daily. During self-heating of SA the temperature rose much as in the corresponding set of bales (A); on each day the higher temperature was recorded by the thermometer nearer the centre of the stack

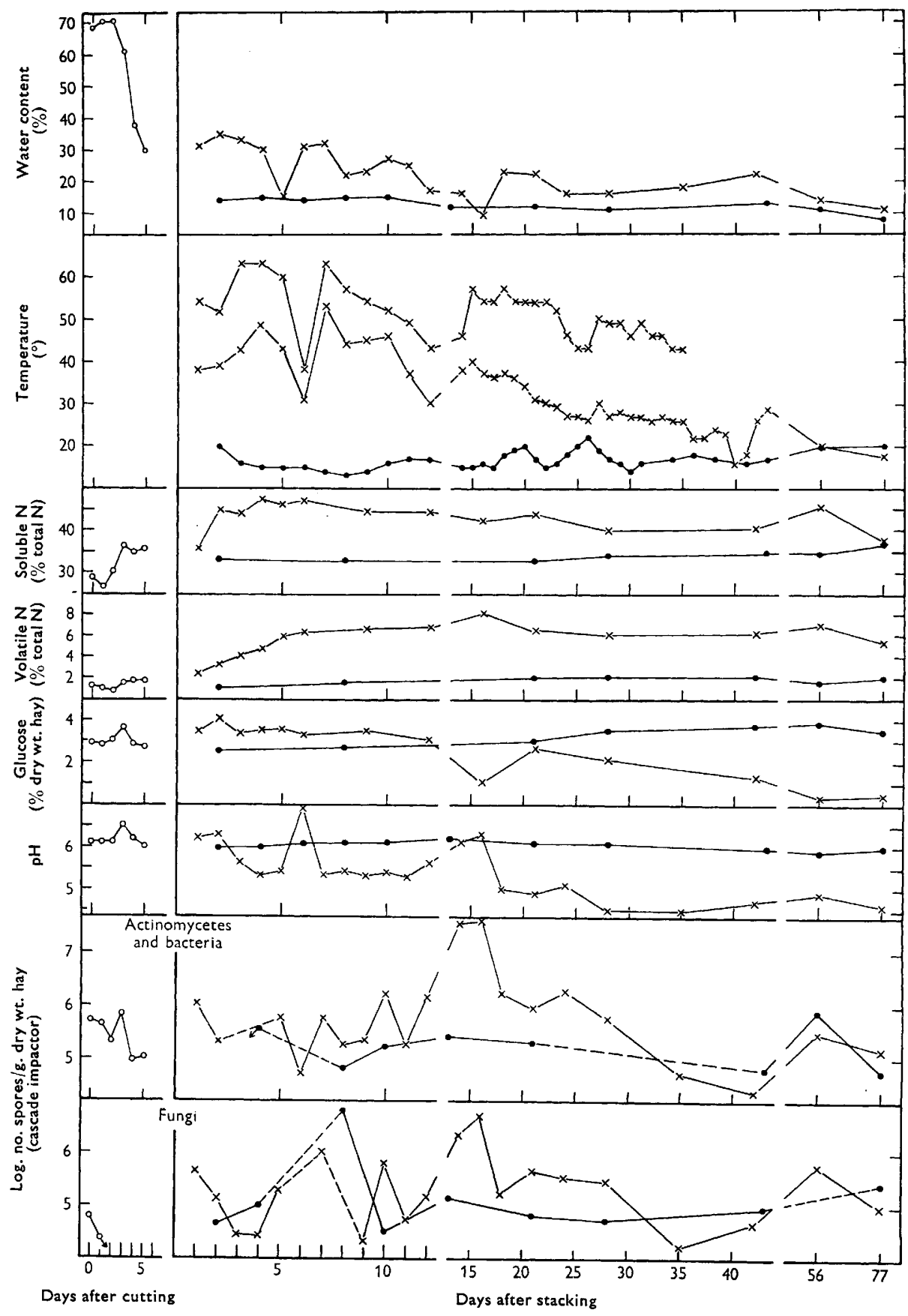

Fig. $3 a$. Changes in wet (SA) and dry (SB) stacked hays of Great Field, made in June 1961. $\times$, Wet stack (SA); $\bullet$, dry stack (SB); O, grass drying in the field. 


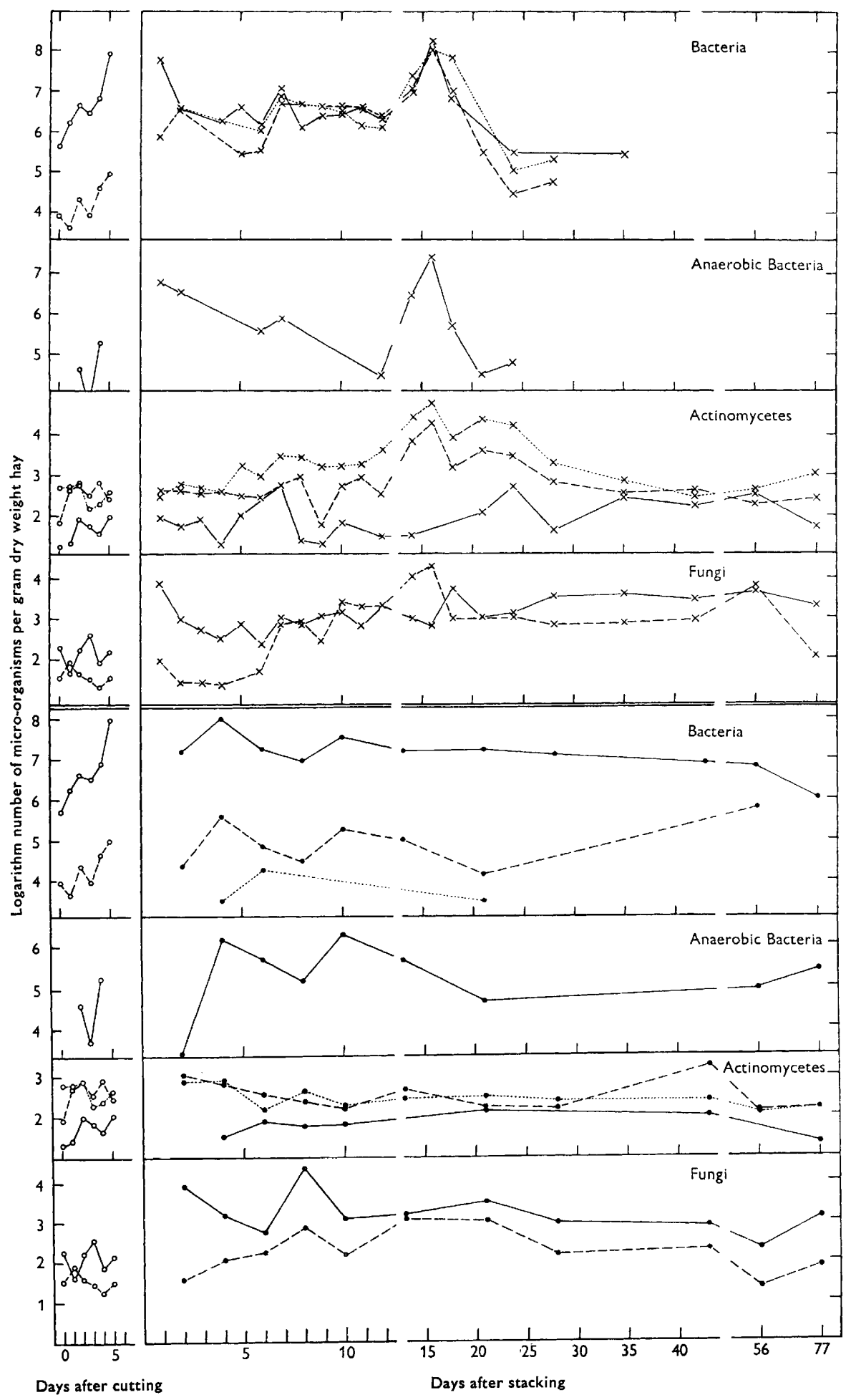

Fig. $3 b$. Changes in the microflora of wet (SA) and dry (SB) stacked hays of Great Field, made in June 1961. $\times$, Wet stack (SA); 9 , dry stack (SB); $O$, grass drying in the field. $-25^{\circ} ;---, 40^{\circ} ; \ldots, 60^{\circ}$. 
(Fig. 3a). Stack SA in the open field fluctuated much more than SB in the barn with outdoor temperature and wind velocity. The moisture content fell eventually to less than $20 \%$, but, as in the bales, there were large variations between successive samples. The temperature of stack SB fluctuated little, and the moisture content remained more or less steady.

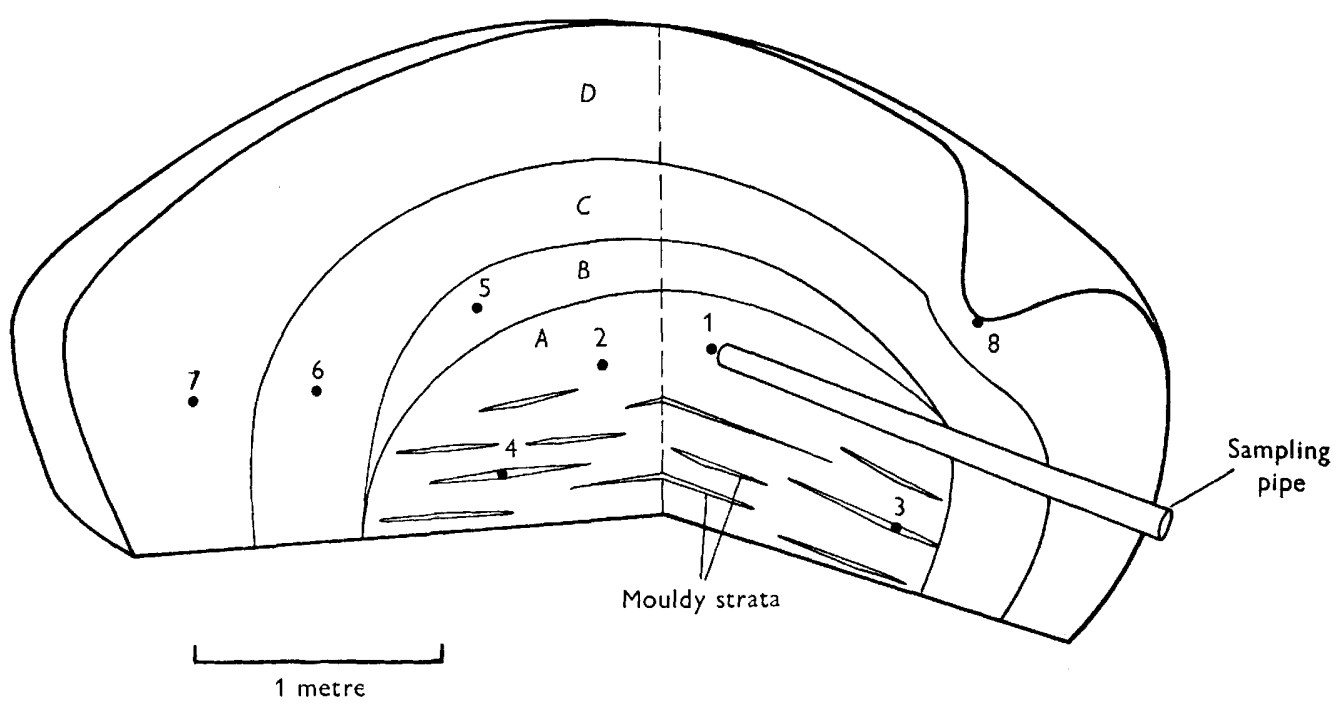

Fig. 4. Schematic diagram of Stack SA after opening. A, Brown hay with mouldy strata; B, grey-brown hay; C, greenish-brown hay; D, greenish-grey hay.

\section{Microbial changes}

Fungi. Thermophilic fungi developed in the wetter parts of the A bales. Most samples had more Absidia and Mucor type spores than Aspergillus. Humicola lanuginosa spores were numerous and reached $8 \cdot 6$ million/g. Paecilomyces variotii developed a little later than the other thermophilic moulds. The B bales had few fungi; Cladosporium was commonest, but Aspergillus glaucus, A. fumigatus, and Penicillium spp. were numerous in some samples. In SA $H$. lanuginosa was the most abundant fungus in the visual counts, but it grows slowly and is under-represented on the Andersen sampler plates, being overgrown by others, including $A$. fumigatus, Absidia and Mucor pusillus. The series of SA samples taken after 186 days (Fig. 4, Table 3) show the differences between parts of the stack. The areas of 'brown' hay had few fungi (SA 25/1 and 2); the white hay (SA 25/3) and a greyish-brown hay just outside the brown core (SA 25/5) had many more. SB, like B, had very few fungi.

Actinomycetes. The Cascade impactor counts of actinomycete and bacterial spores differed greatly, but in many samples of A and SA they were very large. Table 2 shows the abundance of actinomycetes isolated. A and SA had many thermophilic actinomycetes, e.g. Micromonospora vulgaris, whereas B and SB had only a few.

Bacteria. During the 5 days that the hay lay drying in the swath the numbers of bacteria able to grow at $25^{\circ}$ increased steadily. This flora consisted of many different species. Few bacteria grew at $40^{\circ}$ and none at $60^{\circ}$ during this period. Neither 


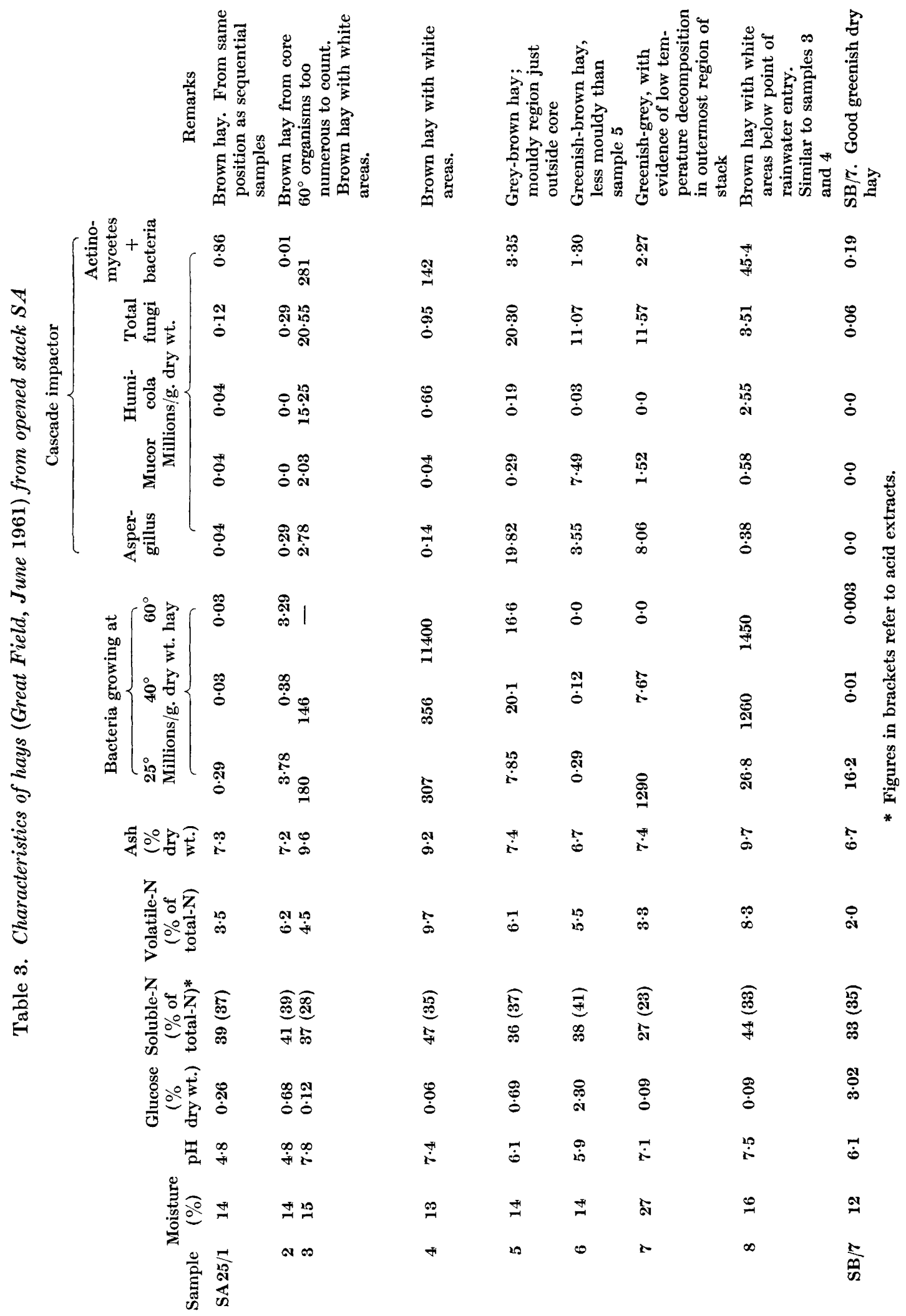


anaerobes nor lactobacilli were detected before 2 days had elapsed, and later their numbers rarely exceeded $10^{5} / \mathrm{g}$. Low numbers of lactobacilli on herbage were reported by Stirling (1953).

In the control bales of dry hay (B series) bacteria isolated at $25^{\circ}$ increased from $8 \cdot 89 \times 10^{6} / \mathrm{g}$. to $2 \cdot 33 \times 10^{8} / \mathrm{g}$. in the 2 days after baling, and decreased to $6 \cdot 4 \times 10^{5} / \mathrm{g}$. during the next 8 days. The peak occurred 1 day after $25^{\circ}$ was reached in the bales, and this flora was also very mixed in composition. Bacteria were fewer at $40^{\circ}$ but numbers fluctuated as at $25^{\circ}$. A few bacteria able to grow at $60^{\circ}$ were found in 9 samples. Anaerobes occurred in most samples in numbers intermediate between those for bacteria at $25^{\circ}$ and $40^{\circ}$, and followed the same general trend. The course of events in the dry stack (SB series) was similar in all respects to that in the dry bales.

In the wet bales (A series) bacteria growing at $25^{\circ}$ remained fairly numerous throughout the experiment and were not greatly influenced by the considerable fluctuations in bale temperature. However, in the early stages the flora was very mixed, with a tendency for organisms forming whitish-buff and yellowish colonies to predominate. Later, whitish punctiform colonies were commonly found. Bacteria at $40^{\circ}$ were scarce at the time of baling but increased rapidly to a maximum 2 days later, when the temperature of the hay was $38^{\circ}$, and remained moderately numerous thereafter. During the first 6 days after baling very few organisms grew at $60^{\circ}$, but an increase was noted on the 7 th day when the temperature of the hay was $50^{\circ}$. In the first few days after baling small white and buff colonies frequently grew at $40^{\circ}$, but 10 days after baling, and coincident with the second temperature peak, the flora took on characteristics that we now associate with growth at high temperatures: flat, thin, white, overlapping colonies with filamentous margins forming almost the sole constituents of this flora. The $60^{\circ}$ flora was essentially similar. The bacterium forming these colonies was identified as Bacillus licheniformis.

During the first 7 days after baling when the numbers of all micro-organisms were rising, lactobacilli were usually detected on acetate agar but usually fewer than $10^{5} / \mathrm{g}$. The numbers were also rather variable, presumably because of the heterogeneity of the material. After 10 days these organisms could not be estimated because the plates of acetate agar always became covered with a dense growth of mucoraceous fungi during overnight incubation. Typically, the $\mathrm{pH}$ value of the medium with this fungus cover was $8 \cdot 0-9 \cdot 6$ as indicated by drops of thymol blue solution placed on the surface of the plate. The presence of ammonia in such alkaline media was indicated by Nessler reagent. Plates covered with fungi began to appear shortly after a marked increase in fungi (at $25^{\circ}$ and $40^{\circ}$ ) and a trend to greater $\mathrm{pH}$ values of the hay (10 days after baling). Keddie's acetate agar was not used in this series after the first 3 weeks of sampling.

The bacterial population of the wet stack (SA series) behaved quite differently from that of the dry stack and from that of the wet bales. Bacteria at $60^{\circ}$ developed quickly in the centre of the stack and reached $3.58 \times 10^{6} / \mathrm{g}$. after $24 \mathrm{hr}$. A peak of $1 \cdot 11 \times 10^{8} / \mathrm{g}$. was reached on the 13 th day, and a subsequent decrease in numbers coincided with a gradual decrease in temperature. The numbers of bacteria at $40^{\circ}$ and $25^{\circ}$ followed the same course as those at $60^{\circ}$ and were of the same order. All the bacteria at these three incubation temperatures formed the same filamentous type of colony of Bacillus licheniformis described above. Bacteria likely to be the 
B. calfactor of Miehe (1907) were not found on the plates. Anaerobes also followed the same trend as the bacteria at $25^{\circ}, 40^{\circ}$ and $60^{\circ}$, but, apart from a peak of $2 \cdot 75 \times 10^{7} /$ g. 13 days after stacking, the numbers were low. Lactobacilli were found in 8 of the sequential samples but they never exceeded $3.62 \times 10^{4} / \mathrm{g}$., the estimate for the first sample. On two occasions, plates of acetate agar were spoiled by rapid growth of mucoraceous fungi and development of alkalinity. These 2 samples (SA/12 and 13) were taken when a marked increase in number of fungi and in $\mathrm{pH}$ was taking place. In sampling after SA/14 there was a decrease in fungi at $40^{\circ}$ and in $\mathrm{pH}$ value, and lactobacilli were again detected.

In the dry stack SB, lactobacilli were detected in the first 6 samples but never exceeded $1.18 \times 10^{4} / \mathrm{g} . \mathrm{SB} / 7$ yielded fungus-covered plates and the acetate agar was not used after SB/8. In the dry bales, lactobacilli were not detected until 1 week after baling. Fungus-covered plates occurred with samples B1/7 and 8 . The occurrence of lactobacilli in the good hays was not associated with any large chemical changes in the hay or with changes in the populations of other micro-organisms.

Biochemical changes (1961). During wilting soluble-N and ash increased, nonreducing sugar decreased and reducing sugar increased (Figs. $2 a, 3 a, 5 a, b$ ). Sucrose, estimated by the increase in glucose formed after acid hydrolysis, decreased more rapidly than fructosan, as shown in the topmost graph of Fig. $5 a$.

After baling, soluble-N did not change much, but on stacking there was a further increase for $\mathbf{2}$ days. Volatile- $\mathrm{N}$ increased soon after baling and also after stacking, where a greater value was reached. Results for amide- $\mathrm{N}$ and total-N are not shown because the changes were small; amide- $\mathrm{N}$ was usually $2-3 \%$ of total- $\mathrm{N}$; the latter was similar to that of W (1960).

The $\mathrm{pH}$ value decreased after baling, as in $1960(\mathrm{~W})$, but less obviously because the samples were more uneven. The subsequent large $\mathrm{pH}$ values of 1960 were not obtained. The $\mathrm{pH}$ values of the stack samples decreased and remained small except where moulding had occurred, as for the sample 16 days after stacking. Mould development may be caused by access of air, as the sample 6 days after stacking was at $\mathrm{pH} 6.9$ : the sampling tool had jammed in the pipe on the previous day and efforts to release it led to access of air and a fall in temperature. The results for titratable acidity (Fig. $5 b$ ) show a clear inverse relationship to $\mathrm{pH}$ value, for both stack and bales.

The decrease in non-reducing sugar and increase in reducing sugar, which started during the wilting period, was maintained for a few days after baling and stacking, until the non-reducing sugar had decreased considerably. Samples from the stack with $\mathrm{pH}$ values less than $\mathbf{5 . 5}$ had comparatively high glucose and total reducing sugar content even 28 days after stacking. Where mould had developed, as for the sample 16 days after stacking, the $\mathrm{pH}$ value was $6 \cdot 3$ and both glucose and total reducing sugar were considerably diminished.

There was no substantial change in ash content after baling or stacking. The complete results are shown along with those for reducing and non-reducing sugar, because oxidative changes in sugars are most likely to be reflected in the ash content; during anaerobic breakdown to lactic acid there is no loss of dry matter, but, if there is oxidation involving loss of dry matter as $\mathrm{CO}_{2}$, the ash content would rise correspondingly. The control bales (B) and stack (SB) showed very little change during the 90 -day period of the experiment. 
Correlations between biochemical and microbial changes. Statistical correlations were determined for all the common biochemical and microbial measurements on batches $\mathbf{A}$ and SA. In the subsequent discussion the $5 \%$ level $(P \leqslant 0.05)$ at least

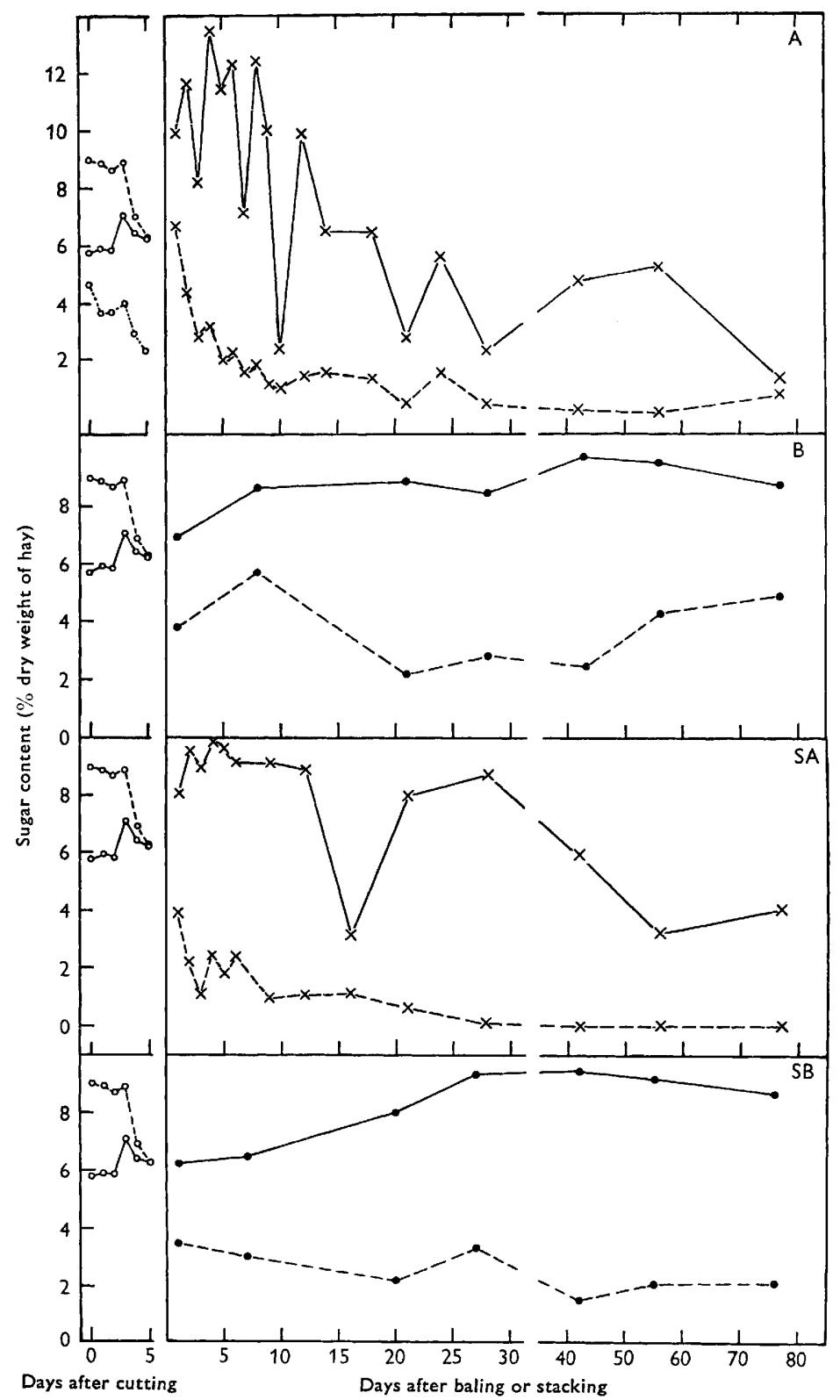

Fig. 5a. Reducing and non-reducing sugars of 1961 Great Field hays. $\times$, Wet bales (A) or stack (SA);, , dry bales (B) or stack (SB); O, grass drying in the field. - $\longrightarrow$, Reducing sugar; - - , non-reducing sugar; ...., sucrose (shown in panel $A$ only).

is required for a significant correlation. Volatile-N is correlated with total numbers of fungi, and $60^{\circ}$ bacteria in the bales; also with $40^{\circ}$ fungi and $60^{\circ}$ actinomycetes in the stack; as noted in 1960 , the $60^{\circ}$ organisms influence the volatile- $\mathrm{N}$ soon after 
baling or stacking. The soluble- and total-N do not correlate with any of the groups of micro-organisms. Reducing sugar, non-reducing sugar and glucose in bales are all negatively correlated with the number of $60^{\circ}$ bacteria, and with $25^{\circ}$ and $40^{\circ}$

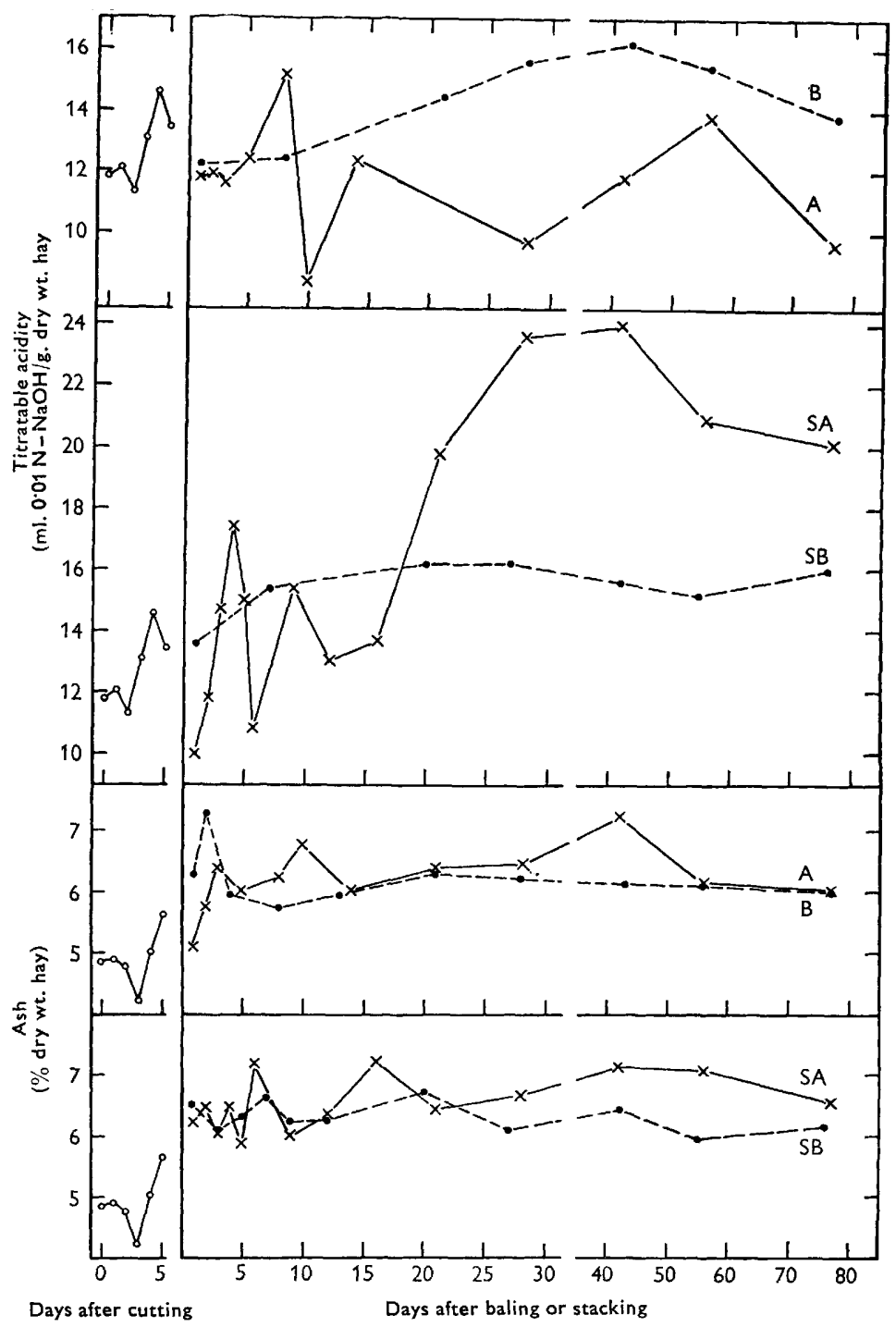

Fig. $5 b$. Titratable acidity and ash content of 1961 Great Field hays. $\times$, Wet bales (A) or stack (SA); $\bullet$, dry bales (B) or stack (SB); O, grass drying in the field.

fungi; the non-reducing sugars are more readily attacked by the micro-organisms, for in addition they are negatively correlated with $40^{\circ}$ bacteria. In the stack, $40^{\circ}$ fungi are responsible for decrease in sugar content. Ash content is positively correlated with $40^{\circ}$ and $60^{\circ}$ bacteria, and with $25^{\circ}$ fungi in the bales, and with $40^{\circ}$ fungi in the stack; the same organisms are responsible for the changes in sugar content, suggesting that loss of dry matter, where it occurs, is mainly a loss of sugar.

Samples from stack (SA) in December 1961 (Fig. 4; Table 3). When cut open in 
December 1961, stack SA consisted of several zones of different-coloured hay. A central brown core extended to about $1 \mathrm{~m}$. above ground level with a diameter of 1-2 m. at its widest and lowest part. This core was surrounded by a mantle of mouldy hay, about $0.5 \mathrm{~m}$. thick, which was brownish on the inner side and greenish on the outer. The outermost layer of the stack consisted of apparently good greenish hay, though this had undergone some decomposition, mainly bacterial, at low temperature (Table 3, sample SA 25/7). The structure of this stack was essentially the same as that of the damp stacks described by Truninger (1929) and Miehe (1930), but the zones were less clearly defined. Some small parts of this stack were composed of hay that did not fit into any of the categories described by Truninger. Such hay occurred in thin strata running at different levels through the central core: it was brown, indicating that it had reached a high temperature, but it was also covered with a heavy deposit of fungus and actinomycete spores. This hay was, moreover, strongly alkaline and somewhat resembled the hay of the very mouldy bales. The reason for the development of mould to this extent in these regions is not clear, but it may have resulted from the uneven distribution of moisture which was characteristic of all the 1961 hay batches. At one point (sample 8) moulding followed penetration of rain into the stack after all sequential sampling had finished.

\section{Experimental hay from Great Knott I Field, June 1961}

Batch $\mathbf{F}$ baled at $35 \%$ water content on 20 June; Batch $\mathbf{G}$ baled at $20 \%$ water content on 21 June.

A mixed grass ley on Great Knott I Field was cut for hay on 19 June and baled as shown above. Unfortunately Batch $\mathrm{F}$ was unevenly dried and did not mould uniformly. Batches $\mathrm{F}$ and $\mathrm{G}$ bales behaved like the Batches $\mathrm{W}$ and $\mathrm{Y}$ from Great Field, June 1960. Details of these 2 batches will be published later with immunological work in connexion with Farmer's Lung disease.

\section{Experimental hay from Lucerne plots on Foster's Field, July 1961}

Batch Lu was baled at $44 \%$ water content on 19 July. A small area of lucerne on Foster's Field was cut on 19 July and placed in the barn at $44 \%$ water content, in a pile $1 \mathrm{~m}$. diameter and $1.3 \mathrm{~m}$. high. This heated spontaneously to $48^{\circ}$ by the 4th day, and the temperature then gradually fell. The water content also fell, reaching $20 \%$ by the 12 th day. Although almost entirely leguminous, this hay moulded in a similar manner to batch $S$ from Great Field, September 1960, with the usual thermophilic moulds (up to 10 million spores/g.) and thermophilic actinomycetes (up to 100 million spores/g.), and when this hay was disturbed a cloud of white dust rose into the air.

\section{Preliminary immunological tests}

In a search for evidence connecting moulding of hay with its ability to cause Farmer's Lung disease, precipitin tests were made in agar gels with crude hay extracts against sera from Farmer's Lung patients (kindly supplied by Dr C. J. Fuller, Royal Devon and Exeter Hospital, and Drs J. Pepys and R. W. Riddell, Brompton Hospital, London). Extracts were made in a laboratory blender from 5 g. chopped hay in $200 \mathrm{ml}$. phenol saline ( $\mathrm{NaCl}, 8 \cdot 5 \mathrm{~g}$.; phenol, 4 g.; water, $1000 \mathrm{ml}$.) and straining through muslin. Tests were done on $2 \times 2$ in. glass slides, with the 
crude extract placed in the holes in the agar $(1.5 \%$ agar, $0.02 \%$ thiomersalate, $0.85 \% \mathrm{NaCl}$ ) at the same time as the serum (Mansi, 1958).

Preliminary tests showed that sera from Farmer's Lung patients formed two (1 to 3) clear, but rather weak, precipitin bands with extracts from three batches of Farmer's Lung hays (H 32, H 44, H 55; described by Gregory \& Lacey, 1963a), and with extracts of experimental hays $\mathbf{E}$ and $\mathbf{R}$ of 1959 described above. Bands were not formed with extracts of batches $\mathrm{N}$ and $\mathrm{L}$ of 1959. Sera from control patients did not form bands with any hay extracts.

In 1960 crude extracts were made of samples of $\mathrm{W}, \mathrm{W} 2$ and $\mathrm{Y}$ during the moulding process at different stages and tested against serum from a person with Farmer's Lung and a control human serum. As soon as the actinomycete count and $\mathrm{pH}$ value had increased, $\mathrm{W}$ and $\mathrm{W} 2$ formed two precipitin bands in tests with the Farmer's Lung serum (Fig. 1 $a$ ). $\mathbf{Y}$ produced one band which was rather diffuse and crossed the bands formed by $W$ and $W 2$, so is considered to indicate an antigen unrelated to those in $\mathbf{W}$. As already pointed out, $\mathbf{Y}$ was not a good control hay as it had heated more than usual during maturation. Some samples of $\mathrm{V}$ produced bands similar to those produced by $\mathbf{W}$, but the 3 early samples of $\mathbf{X}$ did not. Tests were also done during the moulding of pile $S$, and bales $Q$, in 1960 . $S$ also produced two precipitin bands, which were first seen in extracts made 3 days after piling; extracts of $Q$ never produced bands and bands were never produced in tests with the control serum. Tests with other sera during the season gave general confirmation of these results. The tests were discontinued in 1961 because work with purified extracts was in progress at the Brompton Hospital. Evidently there are antigens in mouldy hay that react with sera from Farmer's Lung patients (Pepys, Riddell, Citron \& Clayton, 1962), and these antigens appear as early as 3 days after piling (Batch S).

\section{DISCUSSION}

Hay while drying in the field carries a range of micro-organisms, some epiphytes, some airborne and some derived from the soil. Saprophytes, such as Cladosporium and Alternaria, occur in quantity. The diversity of propagules present suggests that different types of microflora can develop later according to the conditions that prevail in bale or stack at any time.

Experimental baled hay. From 1959 to 1961 the microflora of 22 batches of hay made at different moisture contents was studied (Table 4). Although there was wide variation between the different batches, and sometimes between samples from the same bale, a type of flora could be distinguished characteristic of hays that had become hot because the grass was too wet when baled. Typical examples were $\mathbf{E}$ (1959) and $W(1960)$ with 42 and $46 \%$ moisture, respectively.

Batch $W$ provided the clearest sequence of microbial succession during moulding of a hay of the Farmer's Lung type, because it was wetter and was more uniform than $\mathrm{A}$ and $\mathrm{F}$ (1961). After baling at $46 \%$ water content the temperature of the bale at once began to increase and in $24 \mathrm{hr}$. reached a temporary $48^{\circ}$ maximum. The temperature then fell and reached a temporary $40^{\circ}$ minimum at about $48 \mathrm{hr}$. after baling. During this time Mucor pusillus had evidently been developing, and its spores began to appear in the samples blown at $48 \mathrm{hr}$., reaching their maximum by about the 11th day. This temperature minimum was followed by a further rapid 


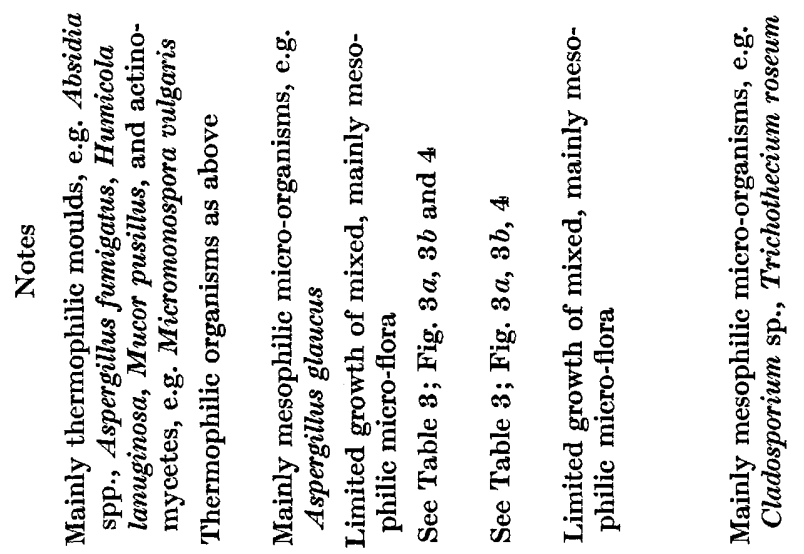

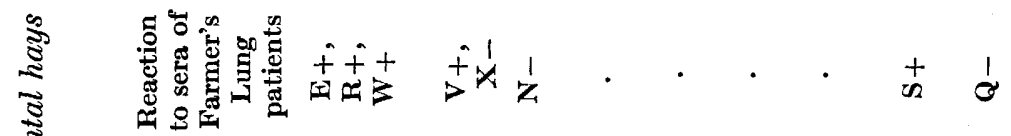

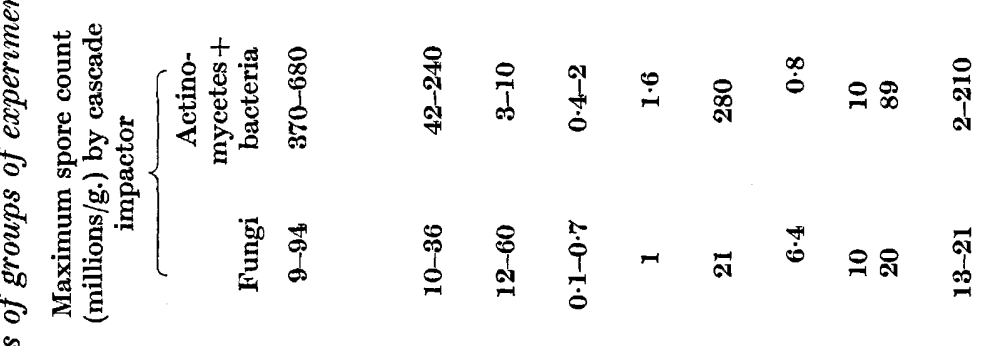
站

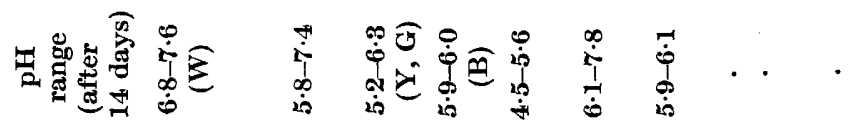

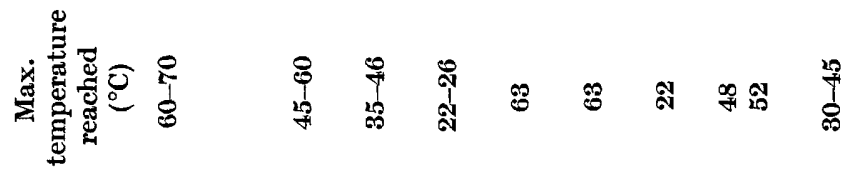

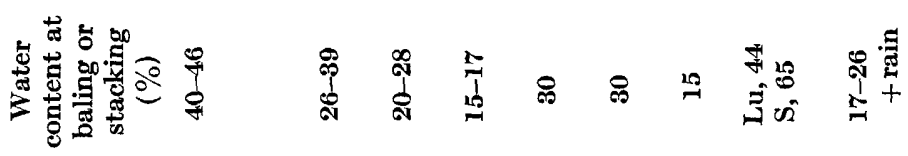

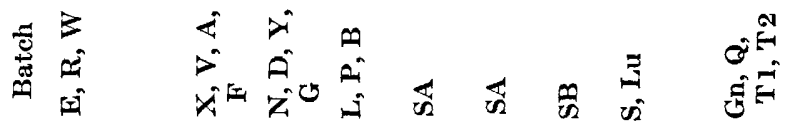

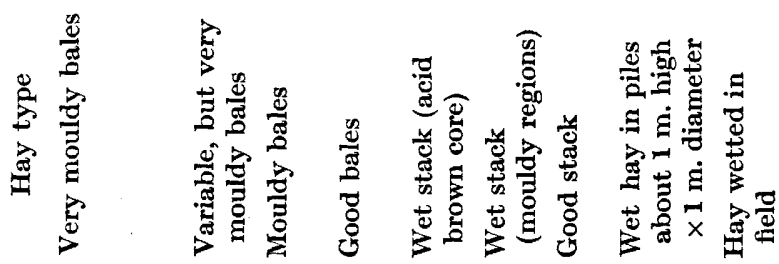


rise to $57^{\circ}$ by the 3rd day, which was retained until the 6th day. During this temperature rise sporulation by Mucor pusillus was increasing. Spores of Absidia, (mainly $A$. ramosa) appeared by the 4 th day and reached their maximum by the 12th day.

On the 6th day, when the temperature of the bales was declining, spores of actinomycetes able to grow at $60^{\circ}$ (mainly Micromonospora vulgaris and Thermopolyspora polyspora) began to appear, and reached their maxima on about the 11th day. A group of actinomycetes able to grow at $40^{\circ}$ appeared by the 8 th day and also reached their maximum on the 11th day. At the same time, 2 other thermophilic moulds (Humicola (Thermomyces) lanuginosa and Aspergillus fumigatus) appeared and reached their maxima by about the 16 th day.

As the mass cooled to about $50^{\circ}$ by the 14th day Aspergillus glaucus and Paecilomyces variotii appeared, as well as numerous actinomycetes able to grow at $25^{\circ}$, and smaller quantities of $\boldsymbol{A}$. nidulans and Penicillium (mainly $\boldsymbol{P}$. piceum?). At this stage, before the mass had dried out, mites, especially Acarus siro, developed in vast numbers and microscopic examination of dust from the hay showed cast exoskeletons and faecal pellets stuffed with fungal spores. The foraging of these mites may account for the fewer mould spores in some of the later samples.

After the bales cool to ambient air temperature, microbial changes are slow. The hay reaches equilibrium with the air at about $15 \%$ water content, and the mites disappear. There is some evidence that Penicillium spp. increase after some months' storage, and Hemispora stellata may also develop during the autumn.

Batches baled at lower water content (e.g. A at $30 \%$ and $F$ at $35 \%$ in 1961) were irregularly dried. Patches rich in actinomycetes, resembling typical Farmer's Lung hays, existed a few centimetres from much drier parts which moulded with Aspergillus glaucus even in the 1st day, and the sequence was confused. But the early development of the thermophilic phycomycetes, Mucor pusillus and Absidia spp., during the phase of increasing temperature was confirmed. A characteristic thermophilic bacterial flora consisting almost entirely of Bacillus licheniformis developed in bales of the $\mathbf{A}$ series after 10 days.

Bales with less moisture such as N, T2 and D (1959) and Y (1960), all with about $\mathbf{2 5} \%$ water, also moulded, but at a lower temperature and with mesophilic moulds such as Aspergillus glaucus and relatively few actinomycetes.

Hays of all these groups contrasted strongly with good hays, typified by $\mathbf{L}$ (1959), $\mathrm{P}$ (1960) and B (1961), with 16, 17 and $15 \%$ water, respectively. In each of these the microflora was sparse and more mixed in species composition than in self-heated bales.

Stacked and baled hays compared (1961). The stacked hays, SA and SB of 1961, provided an interesting comparison with the bales $\mathbf{A}$ and $\mathbf{B}$ made from the same hay in wet or dry condition, respectively, and with the bales of previous years. The dry stack SB behaved essentially as the dry bales of hay B, but the wet stack SA developed quite differently from the wet bales. The large central mass of this stack became much hotter than the corresponding bales and remained hot for a long time. The hay in the centre became brown and acid with a pleasant tobacco-like odour. There was little moulding, but spore-forming bacteria, mainly Bacillus licheniformis, were numerous.

In the wet stack a mantle of mouldy hay developed outside the core of brown hay. 
Sequential samples of SA were taken from the centre of the stack, and the results describe the development of the brown core and not of the mouldy layer outside. After the stack had been cut open in the autumn it was clear that brown hay could also become mouldy. Some of this mould developed where rain had entered the stack, other mouldy material was in thin strata between masses of good brown hay and may have been associated with particularly damp regions of the stack.

Self-heating of hay. Several phases occur during self-heating of hay, although the sequence of events is not entirely clear. Cohn (1890) established that malt sprouts heat in two stages; the first stage reflects plant-enzyme activity and stops at $40^{\circ}$, and the second, caused by mesophilic and thermophilic micro-organisms, stops at $65^{\circ}$. Hay can also show an initial rise followed by a slight drop in temperature (Figs. 1, 2a, 3a), and it seems probable that moist hay starts to heat in the same way as does respiring malt. By contrast, dead plant material will heat up steadily when wetted, the whole temperature rise according to Miehe (1930) being caused by micro-organisms.

There is no reasonable doubt that the rise in temperature is mainly caused by micro-organisms (Miehe, 1930). Temperatures of $60^{\circ}$ can easily be reached in bales, and $65^{\circ}$ in stacks. Stacks can become much hotter, especially when large and wet, but such temperatures cannot be attributed solely to activity of micro-organisms, which, except for bacterial spores, will be killed by short exposure to $80^{\circ}$ or above. Heat production in the outer parts of the stack by continued microbial growth probably prevents loss of heat from the centre. This may sustain or accelerate the purely chemical reactions that must be responsible for rise of temperature above the range $65-75^{\circ}$ ('Truninger, 1929 ; Miehe, 1930). Nevertheless, the possible importance of micro-organisms in predisposing the hay to chemical heating must not be overlooked.

Damp bales tend to heat less than damp stacks. Possibly hay in bales is better aerated than hay in stacks and this better aeration is the cause of heat loss in excess of heat gained by the improved growth of aerobic micro-organisms, especially the fungi and actinomycetes which are so characteristic of bales that have moulded as a result of wet baling.

The biochemical changes during the early stages of hay-making are usually caused by plant enzymes. An increase in soluble-N on wilting is caused by proteolytic activity in the grass which continues until the moisture content falls below $40 \%$; conditions of moist wilting particularly favour continued enzyme action (Kemble \& Macpherson, 1954). After stacking SA, the soluble-N continued to increase for 2 days until well above the values for the bale samples $\mathbf{A}$, suggesting that proteolysis continued in the stack, which remained moist, but not in the bales, which had dried out.

Volatile-N increased more in the stack SA than in the bales, possibly because greater proteolysis in the stack produced more amino acids for deamination. Volatile-N increased soon after baling or stacking (W, 1960; A and SA, 1961), and was correlated with actinomycetes growing at $60^{\circ}$ and with bacteria growing at $60^{\circ}$. In silage, extensive ammonia production usually occurs only in the presence of micro-organisms (Kemble, 1956; Macpherson et al. 1957), but Brady (1960, 1961) reported that plant enzymes produced some ammonia.

When self-heated hay becomes acid, conditions resemble those in silage; the acids come from carbohydrate breakdown (Firth \& Stuckey, 1947). In bales a 
well-insulated core of brown hay has less opportunity to develop than in a stack; whereas SA samples reached as low as $\mathrm{pH} 4 \cdot 5$, the samples from the A bales did not decrease below 5.5 ; when mould developed in the bales the $\mathrm{pH}$ value increased and the sugar content fell, but because of better aeration and quicker drying than in the stack (which reached $\mathrm{pH} \mathbf{7 \cdot 8}$ in the very mouldy region) the highest $\mathrm{pH}$ was only $6 \cdot 7$. The $W(1960)$ bales clearly showed a silage-like trend during the first 6 days, with the $\mathrm{pH}$ value decreasing from $6 \cdot 5$ to $5 \cdot 5$ before increasing to $7 \cdot 6$.

The acidic conditions in silage are usually associated with many lactobacilli (McDonald et al. 1960) but the SA samples with high acidity contained very few lactobacilli; the predominant bacterial species was Bacillus licheniformis, which can grow vigorously between $35^{\circ}$ and $55^{\circ}$ and can form acid from carbohydrates under anaerobic conditions. B. licheniformis was also predominant in the $\mathbf{A}$ bales at the peak of the heating period.

A heated hay is brown, and the intensity of brown colour correlates well with the degree of heating (van der Schaaf, Deijs \& Bosch, 1954). When a brown hay has a large $\mathrm{pH}$ value, moulding has occurred (Truninger, 1929), as in some late SA samples (Table 3), and changes from heating cannot be distinguished from those of moulding. When we incubated sterile hay for 14 days at $60^{\circ}$ in the laboratory, the $\mathrm{pH}$ value decreased from $6 \cdot 0$ to $5 \cdot 1$.

Thus, effects occur from plant enzymes, the growth of mesophilic and thermophilic micro-organisms, and probably from purely chemical reactions; all of these have to be considered in an understanding of the mechanism of moulding hay. Nevertheless, when dealing with bales some general trends have been observed. There seems ample justification for regarding the water content of the herbage at time of baling as the most critical factor which determines the subsequent microbial succession and the degree of heating attained.

We wish to thank Dr J. Pepys and Dr R. W. Riddell (Brompton Hospital, London) and Dr C. J. Fuller (Exeter) for providing sera from patients with Farmer's Lung, Dr G. A. Garton (Rowett Research Institute) for giving details of lipid analysis, Dr T. Gibson (Edinburgh School of Agriculture) for sending us some reference species of spore-forming bacteria. Our thanks are also due to Dr R. Corbaz for the identification of thermophilic actinomycetes, Mr J.H. A. Dunwoody for statistical analysis, Dr N. Walker for a translation of Miehe's paper, Mr J.R. Moffatt and the Rothamsted farm staff for making experimental batches of hay, and Miss Frances Ellingham, Miss Margaret Goodson, Miss Marion Sanders and Mr K. E. Fletcher for technical assistance.

\section{REFERENCES}

Andersen, A. A. (1958). New sampler for collection, sizing and enumeration of viable airborne particles. J. Bact. 76, 471.

Brady, C. J. (1960). Redistribution of nitrogen in grass and leguminous fodder plants during wilting and ensilage. J. Sci. Fd Agric. 11, 276.

Brady, C. J. (1961). The leaf protease of Trifolium repens. Biochem. J. 78, 631.

Browne, C. A. (1929). The spontaneous combustion of hay. Tech. Bull. U.S. Dep. Agric. 141.

BUNCE, M. E. (1961). Humicola stellatus sp.nov., a thermophilic mould from hay. Trans. Brit. mycol. Soc. 44, 372.

Coнn, F. (1890). Ueber Wärme-Erzeugung durch Schimmelpilze und Bakterien. Jber. schles. Ges. vaterl. Kult. 68, 23. 
Firth, J. B. \& Stuckey, R. E. (1947). Spontaneous combustion of hay. Nature, Lond. 159, 624.

Gregory, P. H. \& LACEy, M. E. (1962). Isolation of thermophilic actinomycetes. Nature, Lond. 195, 95.

Gregory, P. H. \& LACEy, M. E. (1963a). Mycological examination of dust from mouldy hay associated with farmer's lung disease. J. gen. Microbiol. 30, 75.

Gregory, P. H. \& LACEy, M. E. (1963b). Liberation of spores from mouldy hay. Trans. Brit. mycol. Soc. 46, 73.

Hofrman, E. J. (1935). Oxidation and gas formation in the spontaneous heating of hay. J. agric. Res. 51, 527.

Hoffman, E. J. \& Bradshaw, M. A. (1937). Losses of organic substance in the spontaneous heating of alfalfa hay. J. agric. Res. 54, 159.

Howard, B. H. (1959). The biochemistry of rumen protozoa. 2. Some carbohydrases in cell-free extracts of Dasytricha and Isotricha. Biochem. J. 71, 675.

Huggetr, A. St G. \& Nixon, D. A. (1957). Use of glucose oxidase, peroxidase and o-dianisidine in determination of blood and urinary glucose. Lancet, ii, 273, 368.

INGRAM, M. \& BARnes, E. M. (1956). A simple modification of the deep shake tube for counting anaerobic bacteria. Lab. Pract. 5, 145.

Kedpre, R. M. (1951). The enumeration of lactobacilli on grass and in silage. Proc. Soc. appl. Bact. 14, 157.

Kemble, A. R. \& Macpherson, H. T. (1954). Liberation of amino acids in perennial rye grass during wilting. Biochem. J. 58, 46.

Kemble, A. R. (1956). Studies on the nitrogen metabolism of the ensilage process. $J$. Sci. Fd Agric. 7, 125.

Long, I. F. (1961). Micro-meteorology. Rep. Rothamst. exp. Sta. 1960, 38.

McDonald, P., Stirling, A. C., Henderson, A. R., Dewar, W. A., Stark, G. H., Davie, W. G., Macpherson, H. T., Reid, A. M. \& Slater, J. (1960). Studies on ensilage. Tech. Bull. Edinb. Sch. Agric. 24.

Macpherson, H. T. (1952). Changes in nitrogen distribution in crop conservation. I. The rate and extent of protein breakdown in ensilage. J. Sci. Fd Agric. 3, 362.

Macpherson, H. T., Wylam, C. B. \& Ramstad, S. (1957). Changes in carbohydrate, nitrogen and organic acid distribution in grass preserved with sodium metabisulphite. J. Sci. Fd Agric. 8, 732.

MansI, W. (1958). Slide gel diffusion precipitin test. Nature, Lond. 181, 1289.

MAY, K. R. (1945). The cascade impactor: an instrument for sampling coarse aerosols. J. sci. Instrum. 22, 187.

MIEHe, H. (1907). Die Selbsterhitzung des Heues. Eine biologische Studie. Jena: Fischer.

Miene, H. (1930). Ưber die Selbsterhitzung des Heues. (2 Auf.) Arb.dtsch. LandwGes. $196,1$.

Nelson, N. (1944). A photometric adaptation of the Somogyi method for the determination of glucose. J. biol. Chem. 153, 375 .

Pepys, J., Riddell, R. W., Citron, K. M. \& Clayton, Y. M. (1962). Precipitins against extracts of hay and moulds in the serum of patients with farmer's lung, aspergillosis, asthma and sarcoidosis. Thorax, 17, 366.

Roethe, H. E. (1937). Spontaneous heating and ignition of hay. Agric. Engng St Joseph, Mich., 547.

Rosebury, T. (1947). Experimental Air-borne Infection. Baltimore: Williams \& Wilkins.

Somogyı, M. (1952). Notes on sugar determination. J. biol. Chem. 195, 19.

Stinling, A. C. (1953). Lactobacilli and silage-making. Proc. Soc. appl. Bact. 16, 27.

Trappe, W. (1938). Modifikation der Jodzahlbestimmungsmethode nach H. P. Kaufmann für kleine und kleinste Fettmengen. Biochem. Z. 296, 180.

Truninger, E. (1929). Allgemeine Beobachtungen und Untersuchungen über Wesen, Ursache und Verlauf der Selbsterhitzung und Selbstentzündung von Dürrfutter. Landw. Jb. Schweiz, 43, 278.

vaN der SchaAf, D., DeiJs, W. B. \& Bosch, S. (1954). Chemisch onderzoek van in verschillende mate gebroeid hooi. Versl. Inst. landb. Onderz. Wageningen, 148.

WaIte, R. \& Gorrod, A. R. N. (1959). The comprehensive analysis of grasses. J. Sci. $F d$ Agric. 10, 317. 